Article

\title{
Spearmint (Mentha spicata) Cultivation in Decoupled Aquaponics with Three Hydro-Components (Grow Pipes, Raft, Gravel) and African Catfish (Clarias gariepinus) Production in Northern Germany
}

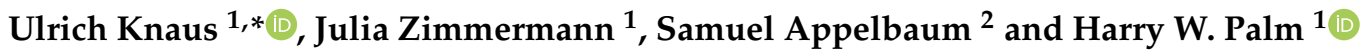 \\ 1 Department of Aquaculture and Sea-Ranching, Faculty of Agricultural and Environmental Science, \\ University of Rostock, D-18059 Rostock, Germany; julia.zimmermann1417@gmail.com (J.Z.); \\ harry.palm@uni-rostock.de (H.W.P.) \\ 2 French Associates Institute for Agriculture and Biotechnology of Drylands, Jacob Blaustein Institute for Desert \\ Research, Ben-Gurion University of the Negev, Sede Boqer Campus, Midreshet Ben-Gurion 8499000, Israel; \\ sappl@bgu.ac.il \\ * Correspondence: ulrich.knaus@uni-rostock.de; Tel.: +49-381-498-3744
}

check for updates

Citation: Knaus, U.; Zimmermann, J.; Appelbaum, S.; Palm, H.W. Spearmint (Mentha spicata) Cultivation in Decoupled Aquaponics with Three Hydro-Components (Grow Pipes, Raft, Gravel) and African Catfish (Clarias gariepinus) Production in Northern Germany. Sustainability 2022, 14, 305. https://doi.org/10.3390/su14010305

Academic Editor: Othmane Merah

Received: 29 November 2021

Accepted: 21 December 2021

Published: 28 December 2021

Publisher's Note: MDPI stays neutral with regard to jurisdictional claims in published maps and institutional affiliations.

Copyright: (C) 2021 by the authors. Licensee MDPI, Basel, Switzerland. This article is an open access article distributed under the terms and conditions of the Creative Commons Attribution (CC BY) license (https:// creativecommons.org/licenses/by/ $4.0 /)$.
Abstract: Mint (Mentha spicata) was cultivated in different hydroponic components: grow pipes, a raft and an ebb-and-flood gravel substrate system irrigated with aquaculture effluents from intensive African catfish (Clarias gariepinus) production under decoupled aquaponic conditions in northern Germany. The spearmint grew well and plant heights above ground were not significantly different between the gravel $(57.7 \pm 13.1 \mathrm{~cm})$, raft $(58.0 \pm 17.7 \mathrm{~cm})$ and grow pipe components $(63.6 \pm 9.9 \mathrm{~cm})$. Root lengths and root fresh weights were two-fold and four-fold higher in raft $(64.3 \pm 20.5 \mathrm{~cm} ; 42.8 \pm 29.9 \mathrm{~g})$ and grow pipes $(59.4 \pm 15.2 \mathrm{~cm} ; 41.3 \pm 25.7 \mathrm{~g})$ compared with gravel substrate $(29.7 \pm 7.8 \mathrm{~cm}$; $9.4 \pm 9.4 \mathrm{~g}$; raft = grow pipes $>$ gravel). Spearmint leaf number was significantly higher in the grow pipes $(770.0 \pm 224.4)$ than in the gravel substrate $(499.8 \pm 228.4)$ with intermediate values in the raft. Significantly highest mean fresh biomass was found in the raft $(1275.6 \pm 33.4 \mathrm{~g})$, followed by grow pipes $(1042.0 \pm 35.8 \mathrm{~g})$ and gravel substrate $(686.3 \pm 98.2 \mathrm{~g}$; raft > grow pipes $>$ gravel). M. spicata, under aquaponics, grows best in grow pipe and raft components. An increase in pipe diameter for the grow pipes and a reduction in the channel height for the raft components could optimize aquaponic culture conditions for both industrial production and the hobby sector in the future.

Keywords: spearmint; African catfish; grow pipes; floating raft; gravel substrate; aquaponics; hydroponics

\section{Introduction}

Aquaponics combines fish and plant production in coupled or decoupled systems [1,2] with different hydroponic culture components. The choice of plants is mainly based on economic aspects, but each plant species has its own requirements in terms of environmental and cultivation parameters, which need to be optimised by providing suitable hydroponic components [3]. Fruiting crops, such as tomatoes (Solanum lycopersicum) or cucumbers (Cucumis sativus), are often cultivated in nutrient-film-technique (NFT) systems [4,5]. Basil (Ocimum basilicum) grew best in an ebb-and-flood gravel substrate system compared to grow pipes (similar to NFT) and raft; [6]) and showed good growth performance with the dynamic root floating technique (DRF; [7]) and in aeroponics [8]. An international study in 2015 showed an earlier preference for raft and media bed components for aquaponic crops [9]. However, the best cultivation techniques in hydroponics for several crops must be reviewed and evaluated for commercial use due to missing information in the literature. 
Mint (Mentha spp., Lamiaceae) production is relatively new in aquaponics. In Germany, the import value of Mentha spp. increased from 227.22 M USD in 2013 to 364.45 M USD in $2020(+37.65 \%)$ [10]. Entire plants and their parts (including seeds) are used primarily in perfumery and pharmaceutical applications or for insecticidal and fungicidal purposes; they can be used fresh or dried, cut or uncut, crushed or powdered [10]. However, potted herbs such as mint are not allowed to be imported due to phytosanitary regulations and thus, the production of mint in garden pots appears predestined in German greenhouse culture [11]. Mentha piperita (peppermint) and Mentha spicata (spearmint) were used as biological filters in aquaponics and removed significant concentrations of nitrogen and phosphate from process water with the production of Nile tilapia (Oreochromis niloticus, [12]). Under desert conditions in the Negev Desert (Israel), Mentha species showed good growth results under coupled brackish water aquaponic conditions [13] and M. spicata produced relevant yield under semi-continuous aquaponics on ebb-and-flood plant tables in pots with the co-production of African catfish (Clarias gariepinus, [14]). Another mint species, field mint (Mentha arvensis), showed the highest mean yield of $1.076 \mathrm{~kg} / 2 \mathrm{~m}^{2}$ in crushed stone media beds compared to river stone $(0.386 \mathrm{~kg})$ and floating raft $(0.916 \mathrm{~kg})$ with the production of common carp (Cyprinus carpio, [15]). These studies demonstrated that Mentha spp. cultivation under aquaponics is well possible and thus, the most efficient hydroponic component should be found to increase plant biomass yield for industrial production.

African catfish (C. gariepinus) was introduced to aquaponics approximately 10 years ago due to its high tolerance to low oxygen levels due to its air breathing physiology and high stocking densities [16]. Due to high demand, aquaculture production in Northern Germany (Mecklenburg-Western Pomerania) increased by 73\% from 2009 (246 t [17]) to 2019 (918 t [18]). Under aquaponic conditions, good growth of C. gariepinus was reported in combination with basil (Ocimum basilicum, $[19,20]$ ), lettuce (Lactuca sativa), cucumber (Cucumis sativus) and tomatoes (Solanum lycopersicum) [20]. Spearmint (M. spicata) seems to be an ideal candidate for combination with African catfish production in aquaponics since its nutrient requirements are generally low [16], water consumption is high and the feed conversion ratios of C. gariepinus are very low [14]. Experimental M. spicata production showed an approximately two-fold increase in crop biomass with intensive catfish production in aquaponics without fertilizer $(13.4 \mathrm{~kg}, 420$ fish per tank) with a four-fold increase in fish biomass, compared to extensive C. gariepinus aquaculture (mint biomass $7.3 \mathrm{~kg}$; 105 fish per tank; [14]). Thus, nutrient levels of intensive African catfish production were adequate for $M$. spicata under aquaponics and aquacultural production of C. gariepinus is possible under very intensive stocking conditions.

In this study, we compared the growth of spearmint (M. spicata) in three different hydroponic components (gravel, raft, grow pipes) under decoupled aquaponic conditions with the intensive production of C. gariepinus in the FishGlassHouse (Northern Germany). The so far available literature on mint cultivation practices in hydroponics and aquaponics is summarized in order to evaluate the observed growth performance. An analysis of the fish and plant production parameters allows recommendations to be made for the best hydroponic components for commercial M. spicata production.

\section{Materials and Methods}

\subsection{Aquaponic System Design in the FishGlassHouse (FGH)}

The study was conducted in the FishGlassHouse (FGH) from 15 June 2017 to 7 August 2017 (54 days) at the University of Rostock (UoR, Rostock, Germany), Faculty of Agriculture and Environmental Sciences (AUF, see Knaus et al., 2020 [6]). The FishGlassHouse consists of a VENLO greenhouse $\left(600 \mathrm{~m}^{2}\right.$, GTW Gewächshaustechnik Werder GmbH, Werder, Germany; automatic climate control Hempel und Rülcker, Gesellschaft für elektronische Klimaregelsysteme $\mathrm{GmbH}$, Dresden, Germany), a water transfer unit $\left(100 \mathrm{~m}^{2}\right)$ and three aquaculture units $\left(300 \mathrm{~m}^{2}\right)$. Non-fertilized aquaculture effluent water from the intensive aquacultural production unit (IAU, $100 \mathrm{~m}^{2}$, PAL Anlagenbau GmbH, Abtshagen, Germany) was used for mint cultivation and staggered stocking principle of African catfish (C. gariepi- 
nus) with 140 fish $/ \mathrm{m}^{3}$ and tank (mean initial biomasses: small fish: $0.21 \mathrm{~kg}$, medium fish: $0.56 \mathrm{~kg}$, large fish: $1.36 \mathrm{~kg}$ ). Mint (M. spicata) cultivation was evaluated in the hydroponic components (i) ebb-and-flood gravel media substrate (gravel), (ii) floating raft components (raft) and (iii) grow-pipes (grow pipes) inside a hydroponic cabin 1_05 (100 $\left.\mathrm{m}^{2}\right)$. The process water flowed only in one direction from the intensive aquaculture unit (IAU) to the hydroponics cabin while maintaining the decoupled aquaponic system design (Figure 1).

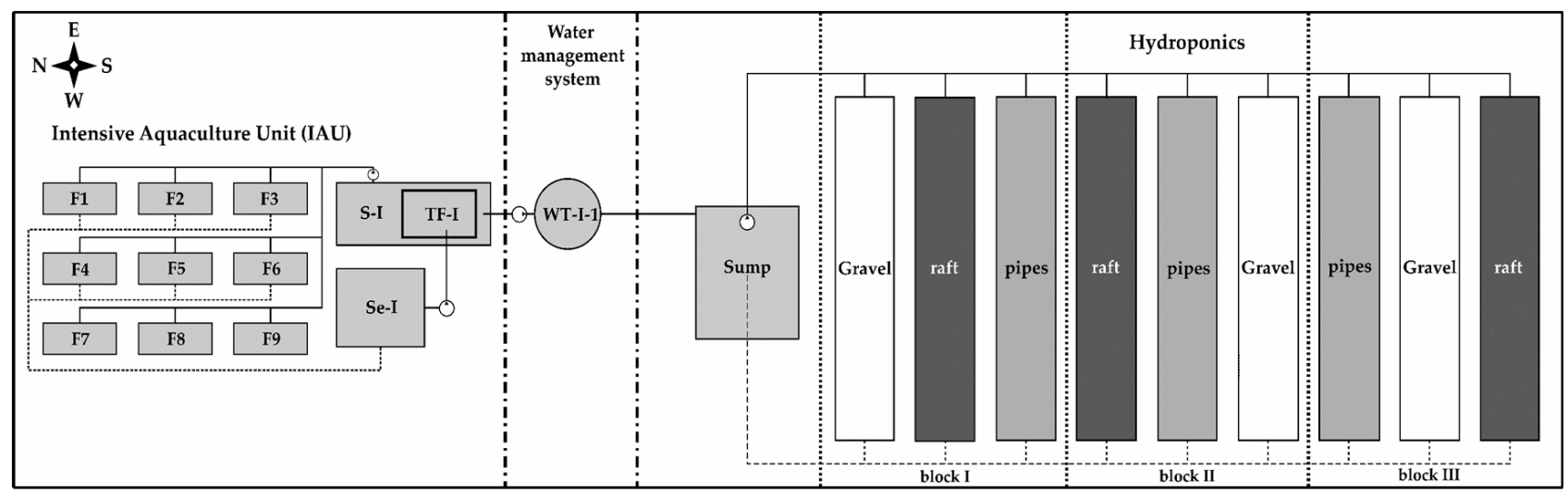

Figure 1. Schematic view of the operational units in the FishGlassHouse. Intensive aquaculture unit (IAU) with fish tanks 1-9 (F1-F9, $\approx 1 \mathrm{~m}^{3}$ ), solids separation unit (sedimenter: Se-I), sump (S-I) and trickling filter (TF-I). The aquaculture unit (IAU) and the hydroponics were connected by a water management system and a water transfer tank (WT-I-1). The aquaculture effluent was pumped into the hydroponics in a sump and circulated through the hydroponics components (gravel, raft, grow pipes). Inflows shown with continuous lines and return flows with dotted lines.

\subsection{Experimental Hydroponic Components}

The hydroponic components were installed in a separate recirculation system (volume in total 1088.42 L, Figure 1). Aquaculture effluent water from the IAU was pumped to the hydroponic components at the start of the study and later two-times per week (Tuesday and Thursday) to a sump $\left(0.4 \mathrm{~m}^{3}\right.$, drained with $537 \mathrm{~L}$ at a surface height of $\left.44 \mathrm{~cm}\right)$ and at a rate of $4 \mathrm{~L} / \mathrm{min}$ to the nine hydroponic components which were grouped in a randomized block design. The water returned from the components to the sump by gravity. Each of the hydroponic components was planted with seven mint seedlings (in total, 63).

The position of the hydroponic components was changed relative to each block and all components were constructed as in Knaus et al. (2020; [6]). The three components of the ebb-and-flood gravel substrate were arranged in glass-fibre-reinforced plastic tanks (GRP tanks, $280 \mathrm{~cm} \times 40 \mathrm{~cm} \times 45 \mathrm{~cm}$, volume: $0.50 \mathrm{~m}^{3}$ used half $0.25 \mathrm{~m}^{3}$ for gravel, total water volume of $255.53 \mathrm{~L}$ ) containing washed Baltic Sea gravel (grain size of 10-40 mm, $393.05 \mathrm{~kg}$ ) equipped with a bell siphon that regulated the water level [21] at the end of the troughs. The ebb-and-flow situation was established by an inflow rate of $4 \mathrm{~L}$ per minute and a water release interval of one minute (six times per half hour). The surface of the gravel substrate was adjusted to the height of the other hydroponic components, as measured from the bottom.

The floating raft (raft)/deep water culture (DWC) consisted of three GRP tanks (total volume of $786.24 \mathrm{~L})$ like the ebb-and-flood gravel components $(280 \mathrm{~cm} \times 40 \mathrm{~cm} \times 45 \mathrm{~cm}$, volume: $0.50 \mathrm{~m}^{3}$ filled with $262 \mathrm{~L}$ water). Polystyrene rafts (URSA XPS DN-III-PZ, surface: $15.75 \mathrm{~cm}^{2}$, height: $20 \mathrm{~mm}$ ) contained seven holes for culturing mint seedlings in grid pots (diameter: $5 \mathrm{~cm}$ ). The water volume was adjusted by PVC standpipes and the water was oxygenated by a membrane air pump (Aqua Medic Mistral 4000, AQUA MEDIC GmbH, Bissendorf, Germany) by air stones.

The grow pipes were built of orange sewage drainage pipes $(275 \mathrm{~cm} \times 12 \mathrm{~cm}$, volume: $16 \mathrm{~L}$, slope: $2.12 \%$, with seven holes ( $5 \mathrm{~cm}$ diameter) with mint seedlings in grid pots each 
spaced $30 \mathrm{~cm}$ apart. Inside the pipes the water level was $2.5 \mathrm{~cm}$ with a total volume of 46.65 L of the three grow pipe components.

\subsection{Plant and Fish Species}

Seeds of mint (M. spicata, Semillas Batlle S.A., Molins de Rei, Spain) were watered for germination, $10 \mathrm{~min}$ in warm water before planting in Grodan rockwool cubes (Grodan ROCKWOOL B.V., Roermond, The Netherlands) and covered with a translucent upper shell on 15.05.2017, within the first four weeks. According to demand, cubes were watered with local fresh water enhanced with a small proportion of commercial fertilizer, Scotts Everris Universol Orange (16-5-25 + 3.4MgO + TE, Everris International BV, Waardenburg, The Netherlands). In the actual experiment, no fertilizer was added to the hydroponic components. After the first three weeks, the translucent upper shell was removed on 08.06.2017 (the day after sowing-DAS: 22) and the seedlings were allowed to grow for another week.

After a total of four weeks, on 15.06.2017 (DAS 29), the seedlings inside the rockwool cubes were transferred to grid pots and wrapped with wool (for better stability) and placed into the nine hydroponic components. The initial plant growth parameters $(n=9)$ one day before the experiment (14 June 2017) were: total length $3.1 \pm 0.5 \mathrm{~cm}$, stem length $1.5 \pm 0.3 \mathrm{~cm}$, root length $1.6 \pm 0.4 \mathrm{~cm}$ and leaf number $8.6 \pm 0.9$. The whole $M$. spicata cultivation time from 15.05.2017 until 02.08.2017 accounted for 77 days after sowing (DAS) and 49 days after transplanting (DAT). Growth parameters of the plant parts (e.g., shoot length, root length) were measured on 07.08.2017 (82 DAS, 54 DAT).

One week before the start of the experiment, fresh water was added to the hydroponic system to ensure optimal water circulation and cleaning. After seedling transplantation, fish process water from the intensive aquaculture unit was added to the hydroponic recirculating system. Once a week, the plant heights (by folding rule) and the number of leaves were determined. In addition, the photosynthetic photon flux density PPFD $\left(\mu \mathrm{mol} / \mathrm{m}^{2} \mathrm{~s}\right)$ was measured using the "Field Scout" solar electric quantum meter (Spectrum Technologies, Inc., Aurora, IL, USA), as well as the light intensity (lx) by "Dr. Meter" (Digital Illuminance/Light Meter LX1330B). On the last day of the experiment, the chlorophyll content (\%) was measured according to the SPAD index (SPAD-502PLUS, Konica Minolta, Inc., Marunouchi, Japan). For the evaluation of mint growth performance, the following parameters were measured for each component: the number of leaves (no), total weight (g), total length $(\mathrm{cm})$, shoot weight $(\mathrm{g})$, shoot length $(\mathrm{cm})$, root weight $(\mathrm{g})$ and root length $(\mathrm{cm})$ $(n=7)$. The dry weight of mint plants was documented after drying in an oven (UF750 plus, Memmert GmbH \& Co. KG, Schwabach, Germany) for three days (at $60{ }^{\circ} \mathrm{C}$ ) and two hours (at $\left.120^{\circ} \mathrm{C}\right)$, modified from [22].

African catfish (Clarias gariepinus) were supplied by Fischgut Nord eG (Abtshagen, Germany, MV) and stocked with three different weight-based size classes (staggered) and 140 fish per tank into the intensive aquaculture unit (IAU) of the FishGlassHouse. The average fish weight (biomass) at the beginning of the experiment was $0.21 \mathrm{~kg}$ for weight class I (small fish, tanks: 3, 6, 9), $0.56 \mathrm{~kg}$ for weight class II (medium fish, tanks: 1, 4, 7) and $1.36 \mathrm{~kg}$ for weight class III (large fish, tanks: 2, 5, 8). Initial and final weights and lengths were taken from nine randomly selected fish samples. Fish were fed by automatic feeders according to an experimental feeding protocol based on actual FCRs (PAL GmbH, Abtshagen, Germany) at 75\% of the recommended feed input. African catfish were fed with Skretting ME-4.5 Meerval 44-14 (France) which consisted of 44\% crude protein, 14\% crude fat, $1.4 \%$ fibre, $8.5 \%$ ash, $2 \%$ calcium, $0.5 \%$ sodium, $1.2 \%$ phosphorus, $42 \mathrm{mg}$ iron, $2.1 \mathrm{mg}$ iodine, $5 \mathrm{mg}$ copper, $16 \mathrm{mg}$ manganese and $200 \mathrm{mg}$ zinc. 


\subsection{Physical and Chemical Parameters}

Physical water parameters were measured including temperature, dissolved oxygen and saturation, conductivity, $\mathrm{pH}$ and redox potential by a HQ40D multimeter (Hach Lange $\mathrm{GmbH}$, Düsseldorf, Germany) at 9:30 each day of the week in the hydroponic sump in triplicates.

Water samples were taken from the sump twice a week (Tuesday and Thursday) and stored at $-7{ }^{\circ} \mathrm{C}$ before water exchange. In the hydroponics, chemical water parameters were analysed including ammonium $\left(\mathrm{NH}_{4}{ }^{+}\right)$, nitrite $\left(\mathrm{NO}_{2}{ }^{-}\right)$, nitrate $\left(\mathrm{NO}_{3}{ }^{-}\right)$, phosphate $\left(\mathrm{PO}_{4}{ }^{3-}\right)$, potassium $\left(\mathrm{K}^{+}\right)$, magnesium $\left(\mathrm{Mg}^{2+}\right)$ and calcium $\left(\mathrm{Ca}^{2+}\right)$ in duplicates, by using a Gallery ${ }^{\mathrm{TM}}$ Automated Photometric analyzer (Thermo Fisher Scientific, Waltham, MA, USA) and standard protocols: $\mathrm{NH}_{4}{ }^{+}$: ISO 7150-1 (DIN 38406-5:1983-10), $\mathrm{NO}_{2}{ }^{-}$: ISO 6777:1984 (DIN EN 26777:1993-04), $\mathrm{PO}_{4}{ }^{3-}$ : EN ISO 6878-1-1986 (DIN 38405 D11-4). TON (total oxidized nitrogen) was analysed by the colorimetric hydrazine method (template: D08896_01 ${ }^{\circledR} 2015$ Thermo Fisher Scientific Inc., Waltham, MA, USA) and N and nitrate by calculation (TON-nitrite).

\subsection{Mathematical and Statistical Analyses}

To evaluate the growth performance of $M$. spicata, the following parameters of the different hydroponic components (gravel, raft, grow pipes) were analysed: leaf number (no), total wet weight $(\mathrm{g})$, total length $(\mathrm{cm})$, shoot weight $(\mathrm{g})$, shoot length $(\mathrm{cm})$, root weight $(\mathrm{g})$, root length $(\mathrm{cm})$ and dry weights of plants and roots $(\mathrm{g})$.

Fish growth parameters, including fish initial length $(\mathrm{cm})$, final length $(\mathrm{cm})$, initial weight $(\mathrm{kg})$, final weight $(\mathrm{kg})$, weight gain $(\mathrm{kg})$, tank initial weight $(\mathrm{kg})$, tank final weight $(\mathrm{kg})$, feed conversion ratio $(\mathrm{FCR}, 1)$, specific growth rate $(\mathrm{SGR}, 2)$, tank weight gain $(\mathrm{kg}$, 3 ) and condition factor $(\mathrm{CF}, 4)$, were calculated for three fish weight classes with three associated tanks in means and standard deviations ( $\pm \mathrm{SD})$.

$$
\begin{gathered}
F C R=\text { fish feed quantity }(\mathrm{kg}) / \text { weight gain }(\mathrm{kg}) \\
\text { SGR }(\% / d)=\left(\ln W_{t}-\ln W_{0}\right) / t \times 100, \\
\text { with } W_{t}=\text { final biomass }(\mathrm{kg}), W_{0}=\text { initial biomass }(\mathrm{kg}), t=\text { time in days } \\
\text { Weight gain }(\mathrm{kg})=\text { final weight }(\mathrm{kg})-\text { initial weight }(\mathrm{kg}) \\
\text { Condition factor }(C F)=W \times 100 \times L^{-3}, \\
\text { with } W=\text { fish weight }(\mathrm{g}) \text { and } L=\text { fish length }(\mathrm{cm})
\end{gathered}
$$

Statistical analysis was done by multiple mean comparisons generated from three subgroups (replicates) of fish tanks, hydroponic components and physical and chemical water parameters $(n=3)$ by one-way analysis of variance (ANOVA) and normally distributed and variance homogeneous data, post hoc by the Tukey-HSD test, or otherwise by the Dunnett-T3 test. The nonparametric Kruskal-Wallis ANOVA (with Bonferroni correction) was used with data of different sample sizes which were not normally distributed. Two experimental groups were analysed using either the $t$-test with normal distributed values or the Mann-Whitney U test. All data were analysed with the SPSS 27 statistical software package [23] and Microsoft Excel [24] at a significance level of $p \leq 0.05$.

\section{Results}

\subsection{Fish Growth}

Fish growth between the three weight classes was different (Table 1). Initial fish weights were significantly lower between small fish $(0.21 \pm 0.03 \mathrm{~kg})$, medium fish $(0.56 \pm$ $0.12 \mathrm{~kg})$ and large fish $(1.36 \pm 0.49 \mathrm{~kg})$. The final weight was highest in the fish of weight class III (large fish: $1.92 \pm 0.53 \mathrm{~kg}$ ), followed by weight class II (medium fish: $1.16 \pm 0.45$ $\mathrm{kg}$ ) and weight class I (small fish: $0.51 \pm 0.08 \mathrm{~kg}$ ). Feed conversion was highest in the fish of weight class III ( $2.69 \pm 1.09)$, followed by weight class II $(1.23 \pm 0.10)$ and weight class I $(0.97 \pm 0.15)$. Specific growth was significantly different between the fish groups, with the 
highest growth observed in the smallest fish of weight class I (1.20 $\pm 0.14 \% / \mathrm{d})$, followed by the medium fish of weight class II $(0.63 \pm 0.05 \% / \mathrm{d})$ and the largest fish of weight class III $(0.23 \pm 0.07 \% / \mathrm{d})$.

Table 1. Clarias gariepinus production parameters of three weight-classes: weight class I $(0.21 \mathrm{~kg}$ : tanks 3, 6, 9), weight class II $(0.56 \mathrm{~kg}$ : tanks $1,4,7)$ and weight class III $(1.36 \mathrm{~kg}$ : tanks 2, 5, 8), means $( \pm \mathrm{SD})$; different letters showing different groups $(p<0.05)$.

\begin{tabular}{|c|c|c|c|c|c|c|}
\hline Parameters & Weight Class I & Weight Class II & Weight Class III & $p-\mathrm{I}^{1}$ & $p$-II ${ }^{1}$ & $p$-III ${ }^{1}$ \\
\hline Fish initial weight (kg) & $0.21 \pm 0.03^{c}$ & $0.56 \pm 0.12^{b}$ & $1.36 \pm 0.49^{\mathrm{a}}$ & 0.001 & 0.001 & 0.003 \\
\hline Fish initial length (cm) & $31.24 \pm 1.59^{c}$ & $43.63 \pm 3.18^{b}$ & $55.40 \pm 5.41^{\mathrm{a}}$ & 0.001 & 0.001 & 0.001 \\
\hline Fish final weight (kg) & $0.51 \pm 0.08^{c}$ & $1.16 \pm 0.45^{b}$ & $1.92 \pm 0.53^{\mathrm{a}}$ & 0.006 & 0.001 & 0.015 \\
\hline Fish final length (cm) & $42.16 \pm 2.35^{b}$ & $55.38 \pm 6.73^{a}$ & $63.31 \pm 6.15^{\mathrm{a}}$ & 0.015 & 0.001 & 0.326 \\
\hline Tank initial biomass weight $(\mathrm{kg})$ & $29.34 \pm 0.53^{c}$ & $88.18 \pm 0.56^{b}$ & $152.59 \pm 1.89^{\mathrm{a}}$ & 0.001 & 0.001 & 0.001 \\
\hline Tank final biomass weight $(\mathrm{kg})$ & $56.28 \pm 3.12^{c}$ & $123.71 \pm 2.66^{b}$ & $173.16 \pm 8.33^{\mathrm{a}}$ & 0.001 & 0.001 & 0.001 \\
\hline Tank biomass weight gain $(\mathrm{kg})$ & $26.94 \pm 3.65^{a, b}$ & $35.53 \pm 3.20^{\mathrm{a}}$ & $20.58 \pm 6.84^{b}$ & 0.155 & 0.313 & 0.021 \\
\hline Initial feed per tank $(\mathrm{g})$ & $416.67 \pm 15.28^{c}$ & $783.33 \pm 5.77^{b}$ & $953.33 \pm 11.55^{\mathrm{a}}$ & 0.001 & 0.001 & 0.001 \\
\hline Initial feed (\%) biomass & $1.42 \pm 0.06^{\mathrm{a}}$ & $0.89 \pm 0.01^{b}$ & $0.62 \pm 0.01^{\mathrm{c}}$ & 0.008 & 0.004 & 0.001 \\
\hline Final feed per tank $(\mathrm{g})$ & $620.00 \pm 17.32^{c}$ & $953.33 \pm 15.28^{b}$ & $1053.33 \pm 11.55^{\mathrm{a}}$ & 0.031 & 0.005 & 0.022 \\
\hline Final feed (\%) biomass & $1.10 \pm 0.07^{\mathrm{a}}$ & $0.77 \pm 0.01^{\mathrm{b}}$ & $0.61 \pm 0.03^{c}$ & 0.031 & 0.005 & 0.022 \\
\hline Feed per tank $(\mathrm{kg})$ & $25.87 \pm 0.83^{c}$ & $43.64 \pm 0.54 \mathrm{~b}$ & $50.45 \pm 0.57^{\mathrm{a}}$ & 0.001 & 0.001 & 0.001 \\
\hline FCR & $0.97 \pm 0.15^{b}$ & $1.23 \pm 0.10^{\mathrm{a}, \mathrm{b}}$ & $2.69 \pm 1.09^{\mathrm{a}}$ & 0.873 & 0.037 & 0.069 \\
\hline $\operatorname{SGR}(\% / \mathrm{d})$ & $1.20 \pm 0.14^{\mathrm{a}}$ & $0.63 \pm 0.05^{b}$ & $0.23 \pm 0.07^{c}$ & 0.001 & 0.001 & 0.005 \\
\hline Condition factor (CF) & $0.67 \pm 0.04^{b}$ & $0.65 \pm 0.05^{b}$ & $0.74 \pm 0.07^{\mathrm{a}}$ & 0.697 & 0.042 & 0.007 \\
\hline
\end{tabular}

${ }^{1}$ Significance, with $p$-I = between fish of weight class I and weight class II, $p$-II = between fish of weight class I and weight class III, $p$-III $=$ between fish of weight class II and weight class III.

\subsection{Plant Growth}

Growth of M. spicata was different between the hydroponic components. The best total plant height (measured with stems and roots) was found in mint cultivated in both grow pipes $(127.7 \pm 20.6 \mathrm{~cm})$ and raft $(127.3 \pm 30.4 \mathrm{~cm})$, followed by the gravel substrate $(90.6 \pm$ $21.9 \mathrm{~cm}$; Table 2). Shortly before the end of the study (49 DAT), plant height above-ground was not significantly different between the groups (gravel: $57.7 \pm 13.1 \mathrm{~cm}$; raft: $58.0 \pm 17.7$ $\mathrm{cm}$; grow pipes: $63.6 \pm 9.9 \mathrm{~cm}$ ). Shoot length was not significantly different between the groups in gravel $(60.9 \pm 16.3 \mathrm{~cm})$, raft $(63.0 \pm 19.7 \mathrm{~cm})$ and grow pipes $(68.9 \pm 11.4 \mathrm{~cm})$. Root length was significantly higher in the raft $(64.3 \pm 20.5 \mathrm{~cm})$ and grow pipe components $(59.4 \pm 15.2 \mathrm{~cm})$, compared to the gravel media substrate $(29.7 \pm 7.8 \mathrm{~cm})$. Total plant fresh weights (stem weight + root weight) were highest and not significantly different between the raft $(182.2 \pm 121.7 \mathrm{~g})$ and grow pipe components $(169.3 \pm 62.6 \mathrm{~g})$ and, due to high variances, not different between the lowest values of gravel substrate $(108.4 \pm 83.4 \mathrm{~g})$ and raft. Root fresh weight showed no differences between the raft components $(42.8 \pm 29.9 \mathrm{~g})$ and grow pipes $(41.3 \pm 25.7 \mathrm{~g})$, whereas the gravel media substrate had the lowest root weight $(9.4 \pm 9.4 \mathrm{~g})$ with a high standard deviation. Leaf number was highest in grow pipes $(770.0 \pm 224.4)$ and raft $(610.5 \pm 371.5)$ and lowest in plants cultivated in the gravel media substrate $(499.8 \pm 228.4)$. The relative chlorophyll content (SPAD) of M. spicata showed no differences between experimental groups (gravel: $31.2 \pm 5.6 \%$; raft: $28.4 \pm 6.3 \%$; grow pipes: $29.7 \pm 4.8 \%$ ).

The highest $M$. spicata total fresh biomass was found in the floating raft components $(1275.6 \pm 33.4 \mathrm{~g})$, followed by grow pipes $(1042.0 \pm 35.8 \mathrm{~g})$ and gravel substrate $(686.3 \pm$ $98.2 \mathrm{~g}$; Table 2), whereas dry mean biomasses were not significantly different between the grow pipes (113.5 $\pm 12.0 \mathrm{~g})$ and raft components (102.2 $\pm 6.1 \mathrm{~g})$ and gravel substrate (65.7 $\pm 15.9 \mathrm{~g})$ was the lowest. Root fresh and dry biomasses were not significantly different between raft (fresh: $299.4 \pm 57.3 \mathrm{~g}$; dry: $18.5 \pm 2.6 \mathrm{~g}$ ) and grow pipes (fresh: $257.5 \pm 4.7 \mathrm{~g}$; dry: $21.0 \pm 3.0 \mathrm{~g}$ ), however, gravel substrate plants showed substantially lower weights of root biomasses (fresh: $59.4 \pm 2.0 \mathrm{~g}$; dry: $6.0 \pm 0.8 \mathrm{~g}$ ). 
The highest total fresh biomass of M. spicata was found in the raft components (3826.7 g), followed by grow pipes (3555.7 g) and gravel substrate (2058.8 g; Table 2). In contrast, total dry biomass was highest in grow pipes $(340.5 \mathrm{~g})$, followed by raft (306.5 g) and gravel components $(197.0 \mathrm{~g})$. The best fresh root biomass was found in raft hydroponics (898.3 g) compared with grow pipes (866.5 g) and gravel substrate (178.3 g), whereas the dry biomass of roots was highest in grow pipes $(63.1 \mathrm{~g})$, followed by raft $(55.6 \mathrm{~g})$ and gravel media substrate components $(18.1 \mathrm{~g})$. Survival of $M$. spicata was, in general, good with $100 \%$, except for two dead plants grown in the gravel substrate components with a total mortality of $9.5 \%$.

Table 2. M. spicata growth performance in different hydroponic components, means $( \pm \mathrm{SD})$, different letters showing different groups $(p<0.05)$.

\begin{tabular}{|c|c|c|c|c|c|c|}
\hline Parameter & Gravel & Raft & Grow Pipes & $p-\mathrm{I}^{1}$ & $p$-II ${ }^{1}$ & $p$-III ${ }^{1}$ \\
\hline Plant height $(\mathrm{cm})^{2}$ & $57.7 \pm 13.1^{\mathrm{a}}$ & $58.0 \pm 17.7^{\mathrm{a}}$ & $63.6 \pm 9.9^{a}$ & 0.464 & 0.464 & 0.464 \\
\hline Shoot length $(\mathrm{cm})^{3}$ & $60.9 \pm 16.3^{a}$ & $63.0 \pm 19.7^{a}$ & $68.9 \pm 11.4^{\mathrm{a}}$ & 0.423 & 0.423 & 0.423 \\
\hline Root length $(\mathrm{cm})^{3}$ & $29.7 \pm 7.8^{b}$ & $64.3 \pm 20.5^{\mathrm{a}}$ & $59.4 \pm 15.2^{\mathrm{a}}$ & 0.001 & 0.001 & 1.000 \\
\hline Total plant height $(\mathrm{cm})^{3}$ & $90.6 \pm 21.9^{b}$ & $127.3 \pm 30.4^{\mathrm{a}}$ & $127.7 \pm 20.6^{a}$ & 0.001 & 0.001 & 0.999 \\
\hline Shoot fresh weight $(g)^{3}$ & $99.0 \pm 75.4^{\mathrm{a}}$ & $139.5 \pm 95.7^{\mathrm{a}}$ & $128.0 \pm 46.6^{\mathrm{a}}$ & 0.367 & 0.396 & 0.946 \\
\hline Root fresh weight $(\mathrm{g})^{3}$ & $9.4 \pm 9.4^{b}$ & $42.8 \pm 29.9^{a}$ & $41.3 \pm 25.7^{a}$ & 0.001 & 0.001 & 1.000 \\
\hline Total plant fresh weight $(\mathrm{g})^{3}$ & $108.4 \pm 83.4^{b}$ & $182.2 \pm 121.7^{\mathrm{a}, \mathrm{b}}$ & $169.3 \pm 62.6^{a}$ & 0.087 & 0.041 & 0.962 \\
\hline Shoot/root ratio $(S: R)$ & $2.1 \pm 0.5^{\mathrm{a}}$ & $1.1 \pm 0.8^{b}$ & $1.2 \pm 0.4^{\mathrm{b}}$ & 0.001 & 0.001 & 0.953 \\
\hline Leaf number (No) & $499.8 \pm 228.4^{b}$ & $610.5 \pm 371.5^{a, b}$ & $770.0 \pm 224.4^{a}$ & 0.587 & 0.002 & 0.270 \\
\hline \multirow[t]{2}{*}{ SPAD $(\%)$} & $31.2 \pm 5.6^{\mathrm{a}}$ & $28.4 \pm 6.3^{\mathrm{a}}$ & $29.7 \pm 4.8^{\mathrm{a}}$ & 0.134 & 0.134 & 0.134 \\
\hline & \multicolumn{6}{|c|}{ Mean biomass per hydroponic component 4} \\
\hline Fresh biomass (g) & $686.3 \pm 98.2^{c}$ & $1275.6 \pm 33.4^{\mathrm{a}}$ & $1042.0 \pm 35.8^{b}$ & 0.001 & 0.005 & 0.029 \\
\hline Dry biomass (g) & $65.7 \pm 15.9^{b}$ & $102.2 \pm 6.1^{\mathrm{a}}$ & $113.5 \pm 12.0^{\mathrm{a}}$ & 0.023 & 0.007 & 0.520 \\
\hline Root fresh weight (g) & $59.4 \pm 2.0^{b}$ & $299.4 \pm 57.3^{\mathrm{a}}$ & $257.5 \pm 4.7^{\mathrm{a}}$ & 0.001 & 0.004 & 0.471 \\
\hline \multirow[t]{2}{*}{ Root dry weight (g) } & $6.0 \pm 0.8^{b}$ & $18.5 \pm 2.6^{\mathrm{a}}$ & $21.0 \pm 3.0^{\mathrm{a}}$ & 0.002 & 0.001 & 0.450 \\
\hline & \multicolumn{6}{|c|}{ Total biomass of hydroponic components 5} \\
\hline Fresh biomass (g) & 2058.8 & 3826.7 & 3555.7 & - & - & - \\
\hline Dry biomass (g) & 197.0 & 306.5 & 340.5 & - & - & - \\
\hline Root fresh biomass $(\mathrm{g})$ & 178.3 & 898.3 & 866.5 & - & - & - \\
\hline Root dry biomass (g) & 18.1 & 55.6 & 63.1 & - & - & - \\
\hline
\end{tabular}

${ }^{1}$ Significance, with $p$-I = between gravel and raft, $p$-II = between gravel and grow pipes, $p$-III $=$ between grow pipes and raft. ${ }^{2}$ Plant height measured above-ground at day 49 DAT and 77 DAS, with a mean $( \pm$ SD) of $59.8 \pm$ $3.3 \mathrm{~cm}(n=3) .{ }^{3}$ Plant growth parameters measured at day 54 DAT and day 82 DAS; total plant height $(\mathrm{cm})=$ plant height $(\mathrm{cm})+$ root length $(\mathrm{cm})$; total plant fresh weight $(\mathrm{g})=$ shoot fresh weight $(\mathrm{g})+$ root fresh weight $(\mathrm{g}) .{ }^{4}$ Mean weights $(g ; \pm \mathrm{SD})$ of three hydroponic components $(n=3)$ with seven cultivated plants. ${ }^{5}$ Addition of 21 plant biomasses $(\mathrm{g})$ cultivated in the respective hydroponic component $(n=3)$.

Individual plants of M. spicata showed differences in total height (plant height + root length) at their respective positions within the hydroponic components (Figure 2). Plants cultivated in the gravel substrate were smaller at the leading edge of the component near the inflow, in plant number 2 and at Positions 5 and 6 and at the end of the channel (plant number 7).

Plants cultivated in raft components were only lower in height at Position 1 compared to grow pipes. The following positions (numbers 2-7) showed no significant differences between mint cultivated in the grow pipes and raft components. $M$. spicata cultivated in the grow pipe components showed the best growth in total height at Position 1 and were similar to spearmint cultivated in raft components at all the positions next to the outflow. 


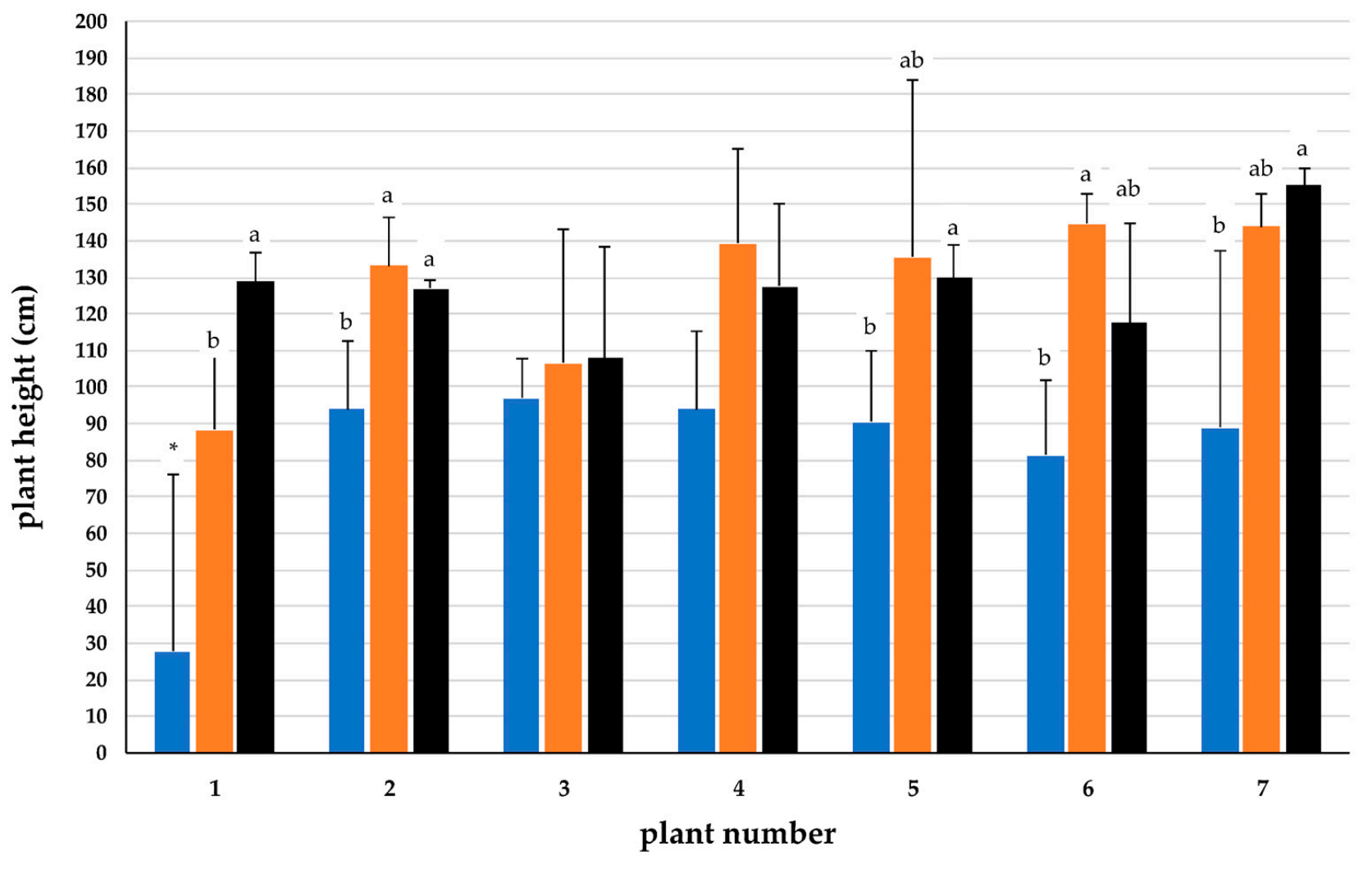

gravel $\quad$ raft grow pipes

Figure 2. M. spicata total plant height (cm; plant height + root length) at selected hydro-component positions (number 1: water inlet to 7: water outlet; day 54 DAT and 82 DAS); different letters indicate different groups $(p<0.05)$; with * for two dead plants in the gravel bed substrate and statistical comparison between raft and grow pipes only.

The plants of the raft components showed the greatest increase in linear regression $\left(y=7.819 x+96.01, R^{2}=0.62\right)$, whereas plants of the grow pipes had a lower increase and a lower precision of the curve $\left(y=2.931 x+115.96, R^{2}=0.19\right)$. M. spicata grown in gravel substrate media beds showed the lowest increase in plant height with regard to the curve $\left(y=5.4202 x+60.271, R^{2}=0.23\right)$ and the mean values were generally lower.

Root fresh weight of mint showed differences from the inflow (Position 1) to the outflow (Position 7) in the specific positions in each hydroponic component (Figure 3). Variances were high and resulted in no significant different mean values in most positions, except in Position 7, with a significantly lower root fresh weight of plants cultivated in the gravel substrate. Generally, the mean values of mint in the gravel substrate were lower $\left(y=1.1448 x+3.909, R^{2}=0.35\right)$ compared to the other groups. Mint grown in the raft components showed the highest linear increase and the highest precision in the coefficient of determination $\left(y=10.743 x-0.1971, R^{2}=0.82\right)$, in contrast to $M$. spicata cultivated in grow pipes with a lower increase of root wet weight from Positions 1 to 7 and a lower value of the coefficient of determination $(\mathrm{y}=4.1074 \mathrm{x}+$ $\left.24.831, R^{2}=0.21\right)$. 


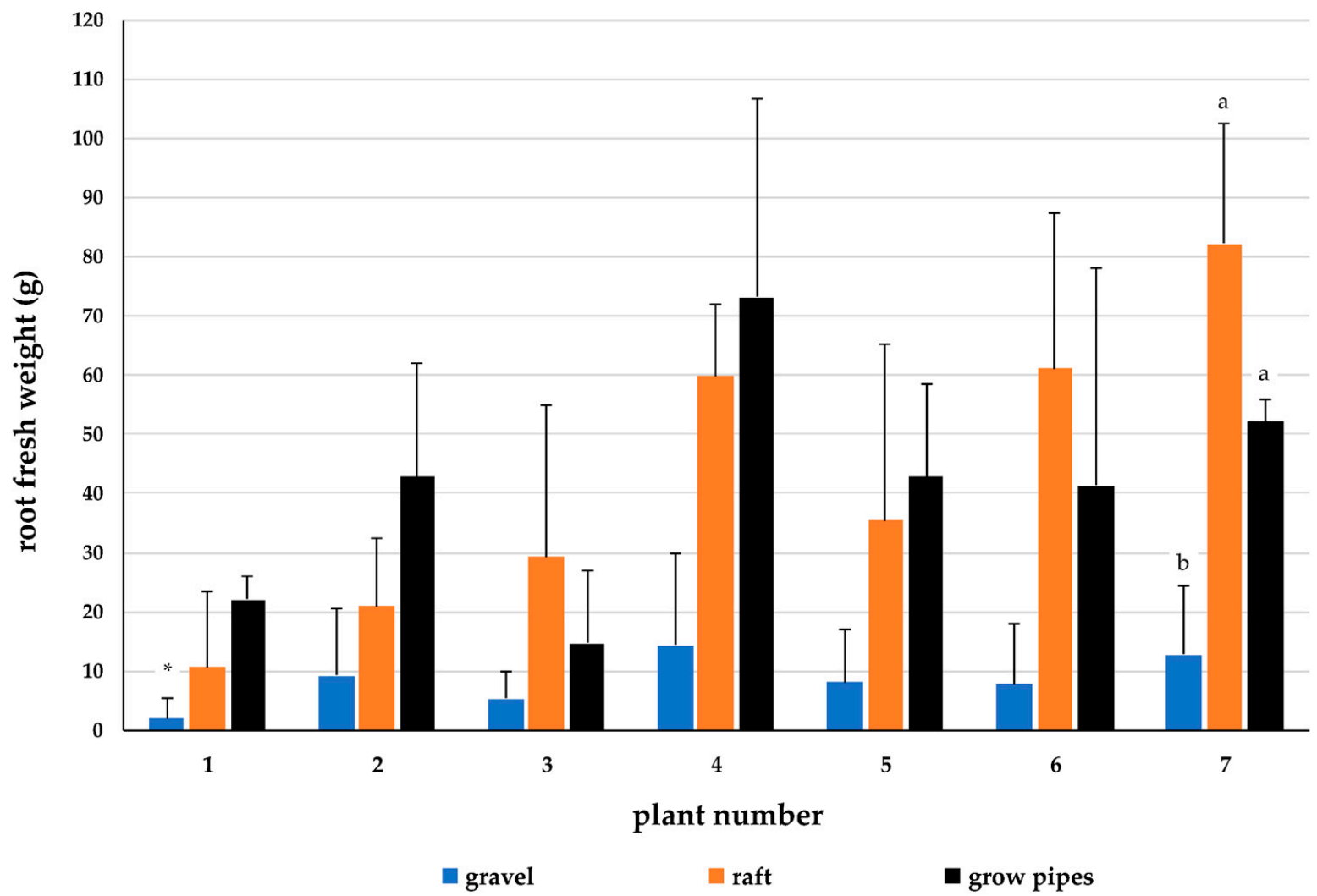

Figure 3. M. spicata root fresh weights ( $g$; means, $\pm \mathrm{SD}$ ) at selected hydro-component positions (number 1: water inlet to 7: water outlet; day 54 DAT and 82 DAS); different letters indicate different groups $(p<0.05)$; with * for two dead plants in the gravel bed substrate and statistical comparison between raft and grow pipes only.

\subsection{Physico-Chemical Parameters}

Physical water parameters between the gravel, raft and grow pipe components were partly different (Table 3). Dissolved oxygen (DO) was a little lower in the gravel components $(7.6 \pm 0.5 \mathrm{mg} / \mathrm{L})$, compared to raft $(8.1 \pm 0.2 \mathrm{mg} / \mathrm{L})$ and grow pipes $(8.1 \pm 0.2 \mathrm{mg} / \mathrm{L})$. Oxygen saturation showed the same distribution with the lowest level in gravel $(90.5 \pm$ $5.8 \%)$ and higher values in raft $(97.2 \pm 1.1 \%)$ and grow pipes $(96.6 \pm 1.7 \%)$. Temperature was not significantly different between groups at approximately $23^{\circ} \mathrm{C}$.

Table 3. Comparison of dissolved oxygen (DO), oxygen saturation (OS), temperature (T), photosynthetic photon flux density (PPFD) and light intensity of hydroponic components (means, \pm SD); different letters show different groups $(p<0.05)$.

\begin{tabular}{|c|c|c|c|c|c|c|}
\hline Parameter & Gravel & Raft & Grow Pipes & $p-\mathrm{I}^{1}$ & $p$-II ${ }^{1}$ & $p$-III ${ }^{1}$ \\
\hline $\mathrm{DO}(\mathrm{mg} / \mathrm{L})$ & $7.6 \pm 0.5^{b}$ & $8.1 \pm 0.2^{a}$ & $8.1 \pm 0.2^{\mathrm{a}}$ & 0.001 & 0.001 & 0.834 \\
\hline OS $(\%)$ & $90.5 \pm 5.8^{b}$ & $97.2 \pm 1.1^{\mathrm{a}}$ & $96.6 \pm 1.7^{\mathrm{a}}$ & 0.001 & 0.001 & 0.818 \\
\hline $\mathrm{T}\left({ }^{\circ} \mathrm{C}\right)$ & $23.2 \pm 1.9^{\mathrm{a}}$ & $23.2 \pm 2.0^{\mathrm{a}}$ & $23.3 \pm 2.0^{\mathrm{a}}$ & 0.834 & 0.834 & 0.834 \\
\hline $\operatorname{PPFD}\left(\mu \mathrm{mol} / \mathrm{m}^{2} \mathrm{~s}\right)$ & $204.5 \pm 154.6^{\mathrm{a}}$ & $236.3 \pm 210.5^{a}$ & $204.6 \pm 141.9^{a}$ & 0.068 & 0.068 & 0.068 \\
\hline Light intensity $\times 100(1 x)$ & $111.4 \pm 93.7^{\mathrm{a}}$ & $119.3 \pm 102.4^{\mathrm{a}}$ & $115.5 \pm 81.7^{\mathrm{a}}$ & 0.100 & 0.100 & 0.100 \\
\hline
\end{tabular}

${ }^{1}$ Significance, with $p$-I = between gravel and raft, $p$-II = between gravel and grow pipes, $p$-III = between grow pipes and raft.

Light parameters showed no significant differences between the groups above each component, in PPFD (gravel: $204.5 \pm 154.6 \mu \mathrm{mol} / \mathrm{m}^{2} \mathrm{~s}$; raft: $236.3 \pm 210.5 \mu \mathrm{mol} / \mathrm{m}^{2} \mathrm{~s}$; grow pipes: $\left.204.6 \pm 141.9 \mu \mathrm{mol} / \mathrm{m}^{2} \mathrm{~s}\right)$ and light intensity $(\mathrm{lx} \times 100$; gravel: $111.4 \pm 93.7 \mathrm{~lx}$; raft: $119.3 \pm 102.4$ lx; grow pipes: $115.5 \pm 81.71 x)$. 
Each hydroponic component was connected to a central pump sump, which showed the following physical mean water parameters $( \pm \mathrm{SD})$ : dissolved oxygen $(8.1 \pm 0.5 \mathrm{mg} / \mathrm{L})$, oxygen saturation $(96.2 \pm 2.1 \%)$, temperature $\left(24.1 \pm 1.8^{\circ} \mathrm{C}\right), \mathrm{pH}(5.8 \pm 0.6)$, conductivity $(1303.2 \pm 231.4 \mu \mathrm{S} / \mathrm{cm}$, Figure 4$)$, salinity $(0.7 \pm 0.1 \%$ o $)$ and redox-potential $(162.6 \pm 24.8$ $\mathrm{mV})$.

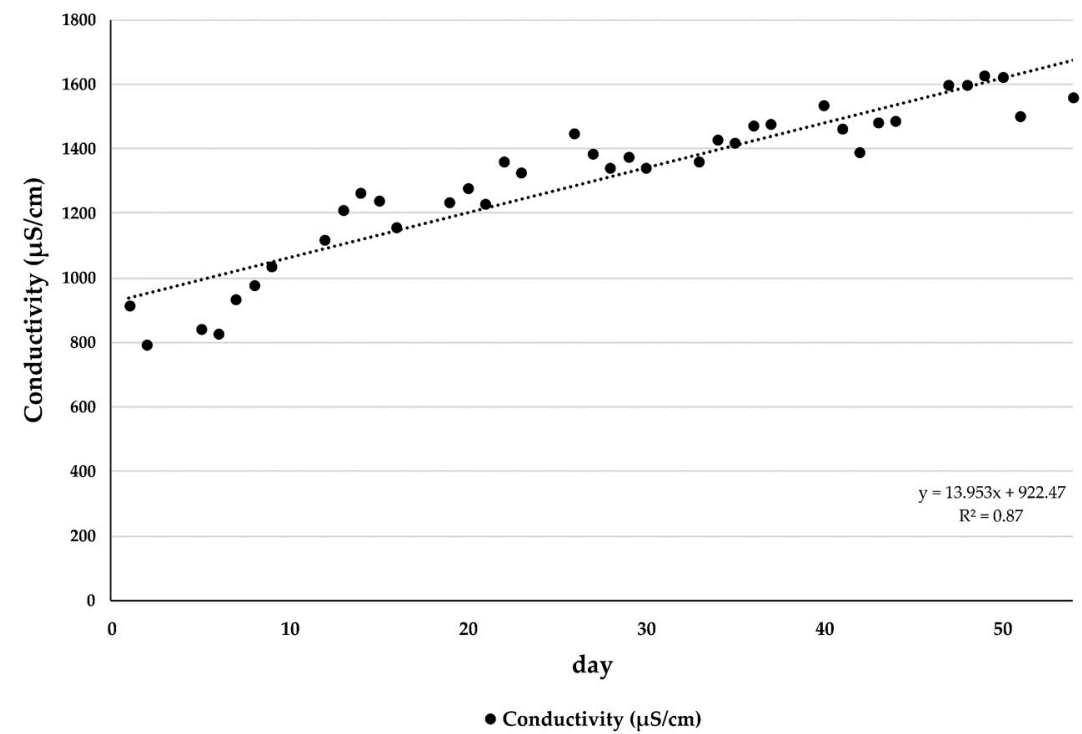

Figure 4. Variation of the electrical conductivity (EC) in the sump of the hydroponic system during the experiment (54 days).

Chemical water parameters (mean, $\pm \mathrm{SD}$ ) of the sump were as follows: $\mathrm{NH}_{4}-\mathrm{N}: 1.17$ $\pm 2.56 \mathrm{mg} / \mathrm{L}, \mathrm{NO}_{2}-\mathrm{N}: 0.01 \pm 0.02 \mathrm{mg} / \mathrm{L}, \mathrm{NO}_{3}-\mathrm{N}: 134.34 \pm 52.68 \mathrm{mg} / \mathrm{L}_{,} \mathrm{PO}_{4}{ }^{3-}-\mathrm{P}: 27.12 \pm$ $9.92 \mathrm{mg} / \mathrm{L}, \mathrm{K}^{+}: 42.40 \pm 14.45 \mathrm{mg} / \mathrm{L}, \mathrm{Mg}^{2+}: 37.17 \pm 11.61 \mathrm{mg} / \mathrm{L}$ and $\mathrm{Ca}^{2+}: 215.15 \pm 68.98$ $\mathrm{mg} / \mathrm{L}$.

The evolution of chemical water parameters during the experiment was different (Figure 5). The highest accumulation in the sump was found in $\mathrm{Ca}^{2+}$ with the greatest level on day 48 (300.68 mg/L), followed by $\mathrm{NO}_{3}-\mathrm{N}$ (maximum at day 48, 204.66 mg/L). The levels of $\mathrm{K}^{+}$was close to $50 \mathrm{mg} / \mathrm{L}$ during the study (maximum at day 29 with $60.67 \mathrm{mg} / \mathrm{L}$ ), $\mathrm{Mg}^{2+}$ and $\mathrm{PO}_{4}{ }^{3-}-\mathrm{P}$ did not reach levels above $50 \mathrm{mg} / \mathrm{L}$.

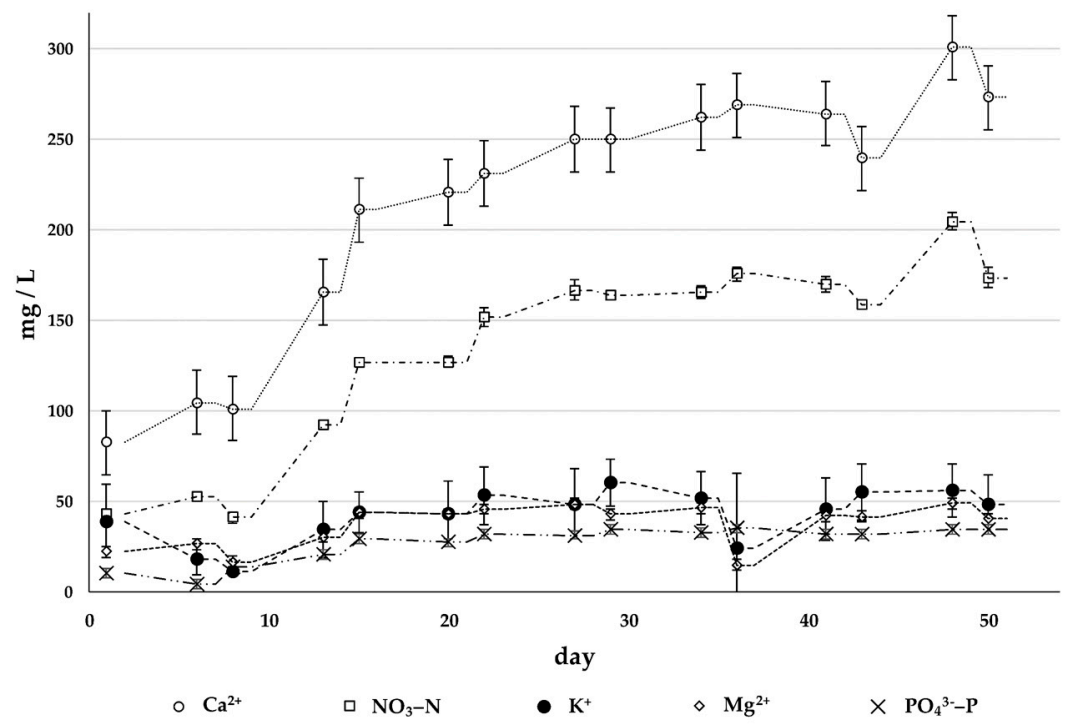

Figure 5. Development of chemical water parameters $\left(\mathrm{Ca}^{2+}, \mathrm{NO}_{3}-\mathrm{N}, \mathrm{K}^{+}, \mathrm{Mg}^{2+}, \mathrm{PO}_{4}{ }^{3-}-\mathrm{P}\right)$ in the hydroponic sump during the experiment (54 days). 


\section{Discussion}

\subsection{Fish Growth}

Fish growth parameters were as expected (Table 1). The initial fish growth parameters were reflected at the end of the experiment with the highest individual fish mass in fish class III (large fish: $1.92 \pm 0.53 \mathrm{~kg}$ ), followed by fish class II (medium fish: $1.16 \pm 0.45 \mathrm{~kg}$ ) and fish class I (small fish: $0.51 \pm 0.08 \mathrm{~kg}$ ). The feed conversion ratio corresponded to the three different fish weights and ranged from $0.97 \pm 0.15$ in small fish to $2.69 \pm 1.09$ in large fish. A comparable feed conversion ratio of 0.98 was reported in small fish of $105.1 \mathrm{~g}$ under intensive aquaculture conditions and a threefold higher stocking biomass of $180.7 \mathrm{~kg}$ [25]. Feed conversion of large fish was higher than reported in other studies and may vary; in the same aquaculture unit of the FGH with the intensive production of adult fish at 1.7 $\mathrm{kg}$, a lower FCR of 1.07 was found [26]. In another recirculating aquaculture system in Ibadan (Nigeria), adult C. gariepinus of $717.0 \mathrm{~g}$ showed a feed conversion of 1.7 [27]. Feed conversion depends on the amount of feed used for production and for fish of weight class I (small fish, initial weight $\approx 200 \mathrm{~g}$ ), the recommended feeding level was $2.6 \%$ body weight per day [28], which was substantially higher than in our study with $1.42 \%$ with a reduction of $46.2 \%$ compared to the level described by Hogendoorn et al. (1983, [28]). For higher fish weight classes, the feeding level should be generally reduced [28]. However, literature for practical fish feed use is scarce for adult C. gariepinus of weight classes from $500 \mathrm{~g}-1.36$ $\mathrm{kg}$. The lower FCR for the highest weight class III (1.36-1.92 kg) can be explained by the generally declining feed conversion with increasing fish age, the influence of uneaten feed and the number of female fish (not counted) where high feed conversion of 4.08 was reported in weight classes from 200-400 g of a C. gariepinus female population as a result of gonadal development [29].

Specific growth of $C$. gariepinus declined with the highest growth in small fish of class I $(1.20 \pm 0.14 \% / d)$, followed by medium fish of class II $(0.63 \pm 0.05 \% / d)$ and large fish of class III $(0.23 \pm 0.07 \% / d)$. For small fish, specific growth was comparable to $C$. gariepinus of $200 \mathrm{~g}$ individual weight with a growth rate of $1.4 \%$ body weight per day under aquaculture conditions [28]. For fish of weight classes II (medium fish) and III (large fish), specific growth was lower than reported for African catfish at, e.g., $295.20 \mathrm{~g}$ with 2.14\%/d and $1458.3 \mathrm{~g}$ with $1.23 \%$ /d held in aquaria [30] or under production conditions, where an SGR of $2.04 \% / \mathrm{d}$ was reported for $1.7 \mathrm{~kg}$ adult fish of intensive stocking density [26]. The lower growth rates were possibly influenced by the higher presence of female fish above approximately $400 \mathrm{~g}$ individual weight, which generally showed a lower somatic growth due to gonad development compared to males [29].

\subsection{Physico-Chemical Parameters in the Hydroponic Components and Sump}

Environmental conditions were optimal for the growth of $M$. spicata in hydroponic components under glasshouse conditions in northern Germany, with a relatively cool, moist and semi-shaded environment [31] and the use of aquaculture effluent without the addition of commercial fertilizer. The temperature inside the hydroponic components $\left(\approx 23{ }^{\circ} \mathrm{C}\right)$ was optimal from $15-25^{\circ} \mathrm{C}$ and a $\mathrm{pH}(5.8 \pm 0.6)$ in the sump in the range of $5.5-7.5$ and in row spacing $(30 \mathrm{~cm})$ from 30-100 cm [32]. Mean conductivity $(1303.2 \pm 231.4 \mu \mathrm{S} / \mathrm{cm}) \mathrm{was}$ higher than reported for $M$. spicata cultivation with $1095.2 \pm 122.4 \mu \mathrm{S} / \mathrm{cm}$ in a fertilizer-free aquaponics system combined with intensive production of African catfish [14] and lower than described for spearmint cultivation in DFT (deep flow technique) with an artificial hydroponic nutrient solution from 21-22 mS/cm [33].

Natural photosynthetic photon flux density (PPFD) was not significantly different and moderate for growth between the hydroponic components (Table 3) with a calculated mean of $215.1 \pm 18.3 \mu \mathrm{mol} / \mathrm{m}^{2} \mathrm{~s}$. In contrast, the best results were obtained under laboratory conditions (LED incubators) in growth chambers at $500 \mu \mathrm{mol} / \mathrm{m}^{2} \mathrm{~s}$ of $70 / 30 \%$ red-blue LEDs, which increased the yield of $M$. spicata essential oil four times compared to field conditions [34]. Further, the assimilation rate of $M$. spicata increased exponentially between PPFD values from 50 to $450 \mu \mathrm{mol} / \mathrm{m}^{2} \mathrm{~s}$ at $100 \%$ irrigation in pot culture, whereas the assim- 
ilation rate was strongly reduced in the slope from 450 to $800 \mu \mathrm{mol} / \mathrm{m}^{2} \mathrm{~s}$ [35], indicating an acceptable range for spearmint growth from $600-800 \mu \mathrm{mol} / \mathrm{m}^{2} \mathrm{~s}$, higher than measured in the present study.

Mentha spp. was identified as a low-nutrient-demand plant [16] and overuse of fertilizer must be avoided [36]. However, several nutrients are essential for good growth under aquaponic conditions. For field production of mint, the application of 100-250 kg nitrogen, $80 \mathrm{~kg} \mathrm{P}_{2} \mathrm{O}_{5}$ and $40 \mathrm{~kg} \mathrm{~K}_{2} \mathrm{O}$ per hectare (calculated $100 \% \mathrm{~N}, 32 \% \mathrm{P}, 16 \% \mathrm{~K}$ ) was recommended. Optimal for medium fertilized soils, for example, farmyard manure is 120-150 kg nitrogen, $60 \mathrm{~kg} \mathrm{P}_{2} \mathrm{O}_{5}$ and $60 \mathrm{~kg} \mathrm{~K}_{2} \mathrm{O} / \mathrm{ha}$, whereby the portions of $\mathrm{P}$ and $\mathrm{K}$ were similar [31]. In contrast, hydroponics cultivation of $M$. spicata with conventional fertilizer (N-P-K ratio of 11-11-23; EC: $1.11 \mathrm{mS} / \mathrm{cm} ; \mathrm{pH}$ 6.12) showed no significant differences in plant height between the cultivation in a float system of $150 \mathrm{~L}$ troughs $(9.4 \mathrm{~cm})$ and a conventional seedbed $(9.4 \mathrm{~cm})$, whereas the number of leaves per plant was different (troughs: 7.9; seedbed: 11.7) after two months of culture [37]. The best marketable fresh weight of M. spicata was found at $189 \mathrm{~g} /$ plant and $270 \mathrm{~g} /$ plant by using a conventional hydroponic nutrient solution of $150 \mathrm{mg} / \mathrm{L} \mathrm{N}, 50 \mathrm{mg} / \mathrm{L} \mathrm{P}$ and $200 \mathrm{mg} / \mathrm{L} \mathrm{K}$ compared to various organic fertilizers such as granular poultry litter, granular composite, granular meal and fish emulsion, whereas conventional fertilizer and poultry litter $(4 \mathrm{~N}-0.9 \mathrm{P}-2.5 \mathrm{~K})$ were not significantly different in spearmint weight with $172 \mathrm{~g} /$ plant and $189 \mathrm{~g} /$ plant [38]. The used quantities of conventional and organic fertilizer often showed a higher value of nitrogen with an optimal level at $150 \mathrm{mg} / \mathrm{L}$ for liquid hydroponics, only slightly higher than observed in our study at $134.34 \pm 52.68 \mathrm{mg} / \mathrm{L} \mathrm{NO}_{3}-\mathrm{N}$. The P ratio was 3 to 4 -fold lower compared to $\mathrm{N}$, which was in accordance with the phosphorus quantity in the hydroponic sump of the FGH at $27.12 \pm 9.92 \mathrm{mg} / \mathrm{L} \mathrm{PO}_{4}{ }^{3-}-\mathrm{P}$, a 4.9 -fold lower level compared with N. Potassium in the present study was substantially lower, below $50 \mathrm{mg} / \mathrm{L}$ (Figure 5), than that reported for the conventional fertilizer solution $(200 \mathrm{mg} / \mathrm{L}$; [38]), with a 3.1-fold lower level in contrast to $\mathrm{N}$. However, the proportion of $\mathrm{K}$ was higher than in the poultry litter with the 1.6 -fold $\mathrm{K}$ level to $\mathrm{N}$ ( $4 \mathrm{~N}-0.9 \mathrm{P}-2.5 \mathrm{~K}$; [38]), which showed good results in the growth of M. spicata. The proportions of N-P-K in the aquaponic process water were acceptable without the addition of conventional fertilizer and only the use of $C$. gariepinus process water, but to reach the values of a commercial hydroponic fertilizer solution, the levels of $\mathrm{N}$ should be increased by $10.4 \%$, of $\mathrm{P}$ by $45.8 \%$ and of $\mathrm{K}$ by $79 \%$.

Calcium $\left(\mathrm{Ca}^{2+}\right)$ was identified as a cellular regulator with high impact on plant growth and development [39]. In plants, calcium deficiency symptoms were reported to include the hooking of stems, browning of veins [40], tip burn and blossom end rot on fruity plants [41]. In aquaponics, the general level of $\mathrm{Ca}^{2+}$ was described as $129.6 \mathrm{mg} / \mathrm{L}$ (hydroponics 160 $\mathrm{mg} / \mathrm{L}$; [42]), substantially lower than that found in the sump of the used recirculating system $(215.15 \pm 68.98 \mathrm{mg} / \mathrm{L})$. During the experiment, the evolution of calcium was continuously increasing (Figure 5), from $82.78 \mathrm{mg} / \mathrm{L}$ at the beginning, to $273.22 \mathrm{mg} / \mathrm{L}$ at the end of the study due to the relatively high portion of $\mathrm{CaCO}_{3}$ in the tap water, which originated from the local Warnow River, as well as to the continuous feed distribution with a calcium content of $2 \%$. The amount of calcium in the present study seemed to be too high, because, as can be seen from the quantitative development, a reduction due to plant uptake of calcium was not observed and the proportion of $\mathrm{Ca}^{2+}$ did not decrease. Analysis of M. spicata leaves from different locations in India showed a calcium content of $12.4 \pm$ $3.5 \mathrm{mg} / \mathrm{g}$ [43], which could indicate a general demand of M. spicata for $\mathrm{Ca}^{2+}$ (possibly also about three times more) that is much lower than that observed in the study. In general, literature on M. spicata's $\mathrm{Ca}^{2+}$ demand is scarce and future experiments should evaluate optimum calcium levels for mint aquaponic production.

The magnesium $\left(\mathrm{Mg}^{2+}\right)$ level was slightly higher $(37.17 \pm 11.61 \mathrm{mg} / \mathrm{L})$ than described for aquaponics with $20.9 \pm 1.1 \mathrm{mg} / \mathrm{L}$ and a little lower compared to hydroponics solution with $40.9 \pm 3.3 \mathrm{mg} / \mathrm{L}$ [42]. A noticeable feature was the nearly identical curve of magnesium to potassium during the experiment (Figure 5), which was influenced from the fish feed input and in particular, by the uptake of $\mathrm{Mg}^{2+}$ by $M$. spicata as the magnesium evolution 
did not increase. Magnesium is essential for photosynthesis and deficiency symptoms were described with the degradation of chlorophyll seen in interveinal chlorosis and, later, necrotic spots that were not observed on cultivated plants [41]. The mean $\mathrm{Mg}^{2+}$ content of M. spicata leaves was reported as $4.83 \pm 0.92 \mathrm{mg} / \mathrm{g}$ [43], a 7.6-fold lower level of the measured magnesium content in the process water. However, magnesium-depleting activities must have predominated because otherwise the proportion of $\mathrm{Mg}^{2+}$ would have increased. A difference of $35 \mathrm{mg} / \mathrm{L}$ can be calculated between the minimum and the maximum, which theoretically seems to be the $\mathrm{Mg}^{2+}$ demand for the present hydroponic system influenced by plant nutrient uptake (of 63 mint plants) and bacterial metabolic processes. In summary, the proportion of magnesium did not completely decrease due to depleting and metabolic processes, thus resulting in a balanced $\mathrm{Mg}^{2+}$ nutrient situation through the feed input alone.

\subsection{Plant Growth Parameters}

\subsubsection{Plant Height Development}

Height of M. spicata above ground was not significantly different between the three hydroponic components from $57.7 \pm 13.1 \mathrm{~cm}$ in gravel, $58.0 \pm 17.7 \mathrm{~cm}$ in raft and $63.6 \pm 9.9$ $\mathrm{cm}$ in grow pipes at 49 DAT or 77 DAS (gravel = raft = grow pipes; Table 2). Generally, plant height was in the range reported for spearmint in field production, from 30-100 cm [31]. Hydroponic cultivation of M. spicata, which developed no flowers, was comparable to older plants after the full flowering stage with $60.1 \mathrm{~cm}$ and with reported earlier heights at full flowering of $54.7 \mathrm{~cm}$ and $43.1 \mathrm{~cm}$ at the pre-flowering stage [44]. The comparison of older fully flowered Iranian mint species, including M. spicata and Mentha longifolia (wild mint [31]), also showed a comparable mean height of $67.84 \mathrm{~cm}$ to younger plants grown in grow pipe components [45]. In contrast, the plant height of M. spicata, grown for two months in a float system under hydroponic conditions, reached a height of $9.4 \mathrm{~cm}$ [37], which was 3.0-3.9-fold lower than the corresponding heights in gravel components with $27.9 \pm 4.5 \mathrm{~cm}, 29.4 \pm 8.5 \mathrm{~cm}$ in raft and $31.9 \pm 3.4 \mathrm{~cm}$ in grow pipes (data not shown). Moreover, a lower M. spicata calculated height of $13.7 \pm 1.0 \mathrm{~cm}$ was reported after 60 days in "PVC pipes" (similar to "grow pipes") in hydroponics and different growth media (vermicompost combined with cocopeat, vermiculite and saw dust, ratio 1:2; [46]), a 2.9 3.2-fold lower value than that found 63 DAS in the gravel $(39.5 \pm 7.1 \mathrm{~cm})$, raft $(40.2 \pm 11.6$ $\mathrm{cm})$ and grow pipe components $(44.2 \pm 4.6 \mathrm{~cm}$, data not shown).

Comparable and slightly higher plant heights from $59.21-77.45 \mathrm{~cm}$ were reported in 8-week-old M. spicata at the full bloom stage, cultivated in a deep flow technique (DFT, styrofoam boards on $15 \mathrm{~cm}$ depth component) with a hydroponic nutrient solution ( $\mathrm{pH} \mathrm{6-7,}$ EC: $21-22 \mathrm{mS} / \mathrm{cm}$ ) in Thailand, relatively similar to our study in shoot length [33]. DFT seemed to have a positive effect compared to the growth of $M$. spicata in the field with soil from 28.87-34.80 cm [33]. Under coupled aquaponic conditions, a lower plant height of $M$. spicata was reported with $46.87 \pm 1.67 \mathrm{~cm}$ after 50 DAT cultivated in hydroponic river stone media substrate components $\left(0.18 \mathrm{~m}^{3}\right)$, similar to our gravel substrate, with the production of Nile tilapia (Oreochromis niloticus) in circular ponds $\left(1.5 \mathrm{~m}^{3}\right.$; [47]). Thus, the pot culture of $M$. spicata in the FishGlassHouse with intensive production of C. gariepinus was slightly lower (14.7\%) at $51.0 \pm 16.9 \mathrm{~cm}$ [14] compared to the mean plant height of $59.8 \pm 3.3 \mathrm{~cm}$ calculated from the three hydroponic components $(n=3$, Table 2$)$.

Our results showed that mint grew faster than previously reported for field cultivation with the first harvest at 90-95 days after planting [31], which was 19\% longer than the harvest at day 77 after sowing in our aquaponic system. Mint was identified as a waterloving plant and in the field, 10-12 irrigations at intervals of 12-15 days were suggested as optimal [31], substantially lower than the continuous watering of M. spicata grown in the hydroponic components. In contrast, M. spicata grown in raft and grow pipes showed greater total heights (raft: $127.3 \pm 30.4 \mathrm{~cm}$; grow pipes: $127.7 \pm 20.6 \mathrm{~cm}$ ) compared to plants cultivated in gravel substrate components $(90.6 \pm 21.9 \mathrm{~cm}$; raft $=$ grow pipes $>$ gravel; Table 2). This is in accordance with spearmint cultivation in DFT hydroponics, 
where spearmint heights were greater in a permanent nutrient solution compared to the cultivation in soil [33]. It has been reported that overirrigation can reduce mint oil yield through oxygen depletion at the roots [36]. Despite this, the content of M. spicata volatile oil as the main economic parameter was more positively influenced by the permanent cultivation in a hydroponic nutrient solution (DFT) than interval-regulated irrigation in soil or in an ebb-and-flood gravel substrate (present study). The supply of amino acids and sulphur compounds in the nutrient solution were also identified as enhancing the content of essential oils, such as carvone and limonene, in M. spicata as a nutritional factor independent from the technical structure [33]. This indicates that the cultivation of $M$. spicata was positively influenced in raft components by adding oxygen via an air pump and in grow pipes due to a faster flow rate of the aquaponic nutrient water. It further shows the possibility of culturing $M$. spicata in permanent aquaponic nutrient solutions, which are technically easier to operate than interval-oriented ebb-and-flood cultivation systems.

Total plant heights of $M$. spicata were significantly different at different positions from the inlet to the outflow of each hydroponic component, except plants on middle Positions 3 and 4 (Figure 2). The best growth was found in grow pipes and raft components, whereas raft plants were only lower in height at Position 1. M. spicata grown in the gravel substrate media beds showed reduced total plant heights and plants of all groups followed a sinusoidal course of growth towards the outflow. The increase in the growth curve was highest for the plants of the raft components $\left(y=7.819 x+96.01, R^{2}=0.62\right)$ with the greatest coefficient of determination, which indicates a steady increase in plant height with the lowest variation in heights. In contrast, $M$. spicata cultivated in grow pipes had a lower increase in height towards the outflow and the determination coefficient was most reduced $\left(y=2.931 x+115.96, R^{2}=0.19\right)$. However, the mean total plant heights were highest, suggesting a positive influence of the grow pipes on the cultivation of spearmint. The opposite was shown in the plants grown in gravel media beds with the lowest height growth $\left(y=5.4202 x+60.271, R^{2}=0.23\right)$; thus, coarse gravel media substrates are not recommended although the oxygen content should have been higher via water drainage. It can be assumed that the higher oxygen input of the ebb-and-flood components concurrently resulted in an increase of $\mathrm{O}_{2}$-consuming effects of, for example, bacteria or algae, thus reducing plant growth. Despite this, ebb-and-flood gravel components were successfully tested with the cultivation of basil (Ocimum basilicum) in the same recirculating system of the FishGlassHouse where plant height was significantly higher $(101.8 \pm 8.3 \mathrm{~cm})$ compared to grow pipes $(96.7 \pm 7.0 \mathrm{~cm})$ after 41 days [6]. However, sigmoid plant height development was also observed in gravel, raft and grow pipe components [6] which indicates, that the length and width ratios of all components have not yet been sufficiently optimised.

In summary, the ideal hydroponic component for the cultivation of M. spicata seems to be a combination of raft and grow pipes, e.g., by increasing the diameter of the pipes, which, however, was already about twice as large $(12 \mathrm{~cm})$ than reported by "A-Frame" vertical NFT structures when cultivating lettuce (Lactuca spp.), with a PVC pipe diameter of $5 \mathrm{~cm}$ [48]. Vertical "A-Frame" structures can contain 16 PVC pipes (8/8), each $6 \mathrm{~m}$ long, which can accommodate a total of 640 lettuce plants [48]. Other vertical A-shaped frame structures with varying dimensions and nutrient management methods were reported for the cultivation of onion (Allium cepa; [49]) and garlic (Allium sativum; [50]) and could be optimised in future studies for mint cultivation, with attention to the sigmoidal evolution of plant height.

\subsubsection{Plant Biomass Development}

Plant fresh weights were highest in raft $(182.2 \pm 121.7 \mathrm{~g})$ and grow pipe components $(169.3 \pm 62.6 \mathrm{~g})$ and lowest in gravel bed media substrates $(108.4 \pm 83.4 \mathrm{~g})$, with a significantly greatest mean fresh biomass in raft $(1275.6 \pm 33.4 \mathrm{~g})$, followed by grow pipes $(1042.0 \pm 35.8 \mathrm{~g})$ and gravel media substrate $(686.3 \pm 98.2 \mathrm{~g}$; raft > grow pipes > gravel; Table 2). In terms of raft and grow pipes, this is in accordance with the aquaponic pot culture of M. spicata irrigated with process water from intensive (190.7 $\pm 105.6 \mathrm{~g} / \mathrm{plant})$ 
and extensive (165.5 $\pm 71.7 \mathrm{~g} /$ plant) C. gariepinus production [14]. Spearmint cultivated in the gravel substrate media beds showed a significantly different mean fresh biomass reduction (per hydroponic component), from 34.1-46.2\%, to grow pipes and raft components and was 42.1-46.2\% lower in total biomass. Further, mean dry biomasses and total dry biomasses were 1.6-1.7-fold lower compared to plants cultivated in raft and grow pipe components. This observation is comparable to an increased foliage biomass in M. spicata when the irrigation interval was expanded under hydroponic conditions [35]. The same effect was found in peppermint (Mentha piperita), where irrigation reduction resulted in a decrease in stem fresh and dry weight [51]. Furthermore, in aquaponics, the growth of Mentha arvensis was reduced 2.4-fold by using river stone media beds (biomass yield $0.386 \pm 0.02 \mathrm{~kg})$ in contrast to floating raft $(0.916 \pm 0.03 \mathrm{~kg})$ with permanent water contact, combined with the production of common carp (Cyprinus carpio; [15]). In the present study, M. spicata biomass yield was significantly reduced by partial process water contact in the ebb-and-flood gravel components. Permanent irrigation had a positive impact on total spearmint yield and increased biomass by approximately two times. The total yield was highest in the raft components with a difference of about 7.1\% compared to grow pipes. However, the mean biomasses did not show a significant difference in total dry biomass; thus, both raft and grow pipes components can be recommended for the production of $M$. spicata in aquaponics.

\subsubsection{Plant Root Development}

Root lengths and fresh weights of $M$. spicata were highest in raft (length: $64.3 \pm 20.5$ cm; weight: $42.8 \pm 29.9 \mathrm{~g}$ ) and grow pipes (length: $59.4 \pm 15.2 \mathrm{~cm}$; weight: $41.3 \pm 25.7 \mathrm{~g}$ ) and significantly different to the gravel media substrate (length: $29.7 \pm 7.8 \mathrm{~cm}$; weight: $9.4 \pm 9.4$ g; raft = grow pipes $>$ gravel; Table 2 ) and variances were generally high. The differences in dry and fresh spearmint root biomasses were 70-80\% higher in raft and grow pipes than in the gravel media substrate (mean biomass per hydroponic component and in total yield). Apparently, there were specific effects of nutrient and water supply in the gravel substrate that resulted in comparable growth of plant heights similar to the other groups but did not prolong root growth in the gravel components. Literature about root weight and length of M. spicata in hydroponics and aquaponics is scarce. For M. spicata grown in DFT hydroponics (nitrogen level of $150 \mathrm{mg} / \mathrm{L}$ ), a slightly lower cultivation time $(\approx 45$ days), a root length of $25.66 \pm 2.67 \mathrm{~cm}$ and root fresh weight of $21.00 \pm 3.23 \mathrm{~g} / \mathrm{plant}$ were reported [52], 13.6\% lower compared to gravel plants and 56.8-60.1\% lower than in grow pipes and raft components. In contrast, root fresh weight was $55.2 \%$ lower in the gravel media substrate, as shown by Chrysargyris et al. (2017; [52]). Despite this, the fresh weight of M. spicata cultivated in raft and grow pipe components was approximately $50 \%$ higher. For peppermint (M. piperita), a root length of $31.66 \mathrm{~cm}$ and a root fresh weight of $29.66 \mathrm{~g}$ was reported after four months (one month more than in this study) in the greenhouse culture [53] and the root length was comparable to the gravel substrate but about two times lower than the root length in the float and grow pipe components. In contrast, root weights in the present study were about 1.4-fold higher in raft and grow pipes than in the greenhouse culture of peppermint [53]. Furthermore, a root fresh weight of 32.94 $\mathrm{g}$ was reported for $M$. arvensis after three months of pot culture under glasshouse conditions, which was relatively similar to the root growth in the raft and grow pipe components [54]. This demonstrates that root growth of $M$. spicata under permanent irrigation in the raft and grow pipes components resulted in values within the range documented for M. spicata and other mint species, but not for spearmint cultivated in the ebb-and-flood gravel media substrate.

M. spicata has rarely been cultivated in aquaponics. An investigation under aquaponic conditions in the FishGlassHouse in pot culture showed non-significant root fresh weights of $8.3 \pm 3.4 \mathrm{~g}$ in the hydroponic control group and $7.5 \pm 3.1 \mathrm{~g}$ in intensive and $6.8 \pm 3.6 \mathrm{~g}$ in extensive irrigation with unfertilized fish process water of $C$. gariepinus after a comparable experimental duration of 53 days [55]. The calculated mean fresh weight of $7.5 \pm 0.8$ 
g [55] was $20 \%$ lower compared to mint cultivated in gravel media substrates and about $80 \%$ lower compared to plants cultivated in raft and grow pipes. Thus, root growth of spearmint in the latter was substantially higher than in the studies described and raft and grow pipe components obviously had a positive influence on root growth by permanent water contact. It is known for barley (Hordeum vulgare), that increased nutrient supply (nitrogen, phosphorus) can cause a 2.3-3-fold massive stimulation of root growth [56], which corresponds to the root length ratios of grow pipes/gravel (2.0) and raft/gravel (2.2) and indicates a better nutrient supply for these two components.

Ratios of shoot: root (S:R) were significantly higher in M. spicata grown in the gravel media substrate components $(2.1 \pm 0.5)$, influenced by reduced root lengths compared to raft $(1.1 \pm 0.8)$ and grow pipes $(1.2 \pm 0.4$; gravel $>$ raft $=$ grow pipes; Table 2$)$. Differences in S:Rs are mainly affected by the supply of assimilates, mineral nutrients and the irrigation interval [57]. However, shoot lengths were not different between experimental groups and did not influence $S: R$ in contrast to the higher root lengths in raft and grow pipe components. It has generally been stated that drought stress can cause a greater reduction in shoot height than the reduction in root length [58]. This is in accordance with the observed significant reduction of $M$. spicata shoot heights irrigated $50 \%$ below the maximum amount of water (in contrast to above $50 \%$ and $100 \%$; [35]). Shoot lengths in our study were not significantly different as an indication of sufficient water supply particularly in ebb-andflood components. Plants exposed to drought stress, e.g., common bean (Phaseolus vulgaris), developed longer roots to absorb water from deeper soil areas [58]. The effect of drought on root stress was not observed as plants in the ebb-and-flood components (with intervalorientated water contact) had roots about 2-fold shorter, not longer, than those grown in the raft and grow pipe components with an oversupply of water. It can be assumed that the roots in the grow pipe components were exposed to a deficiency of water. However, this hypothesis must be rejected, as the roots in grow pipes and raft components did not have different lengths and raft hydroponics are known to hold the highest proportion of process water by volume.

The opposite effect of drought stress is waterlogging stress [58], which can cause reduced shoot growth, root rot, root anoxia and root length reduction due to the decrease of oxygen content at the roots by the transition to anaerobic chemical conditions and the formation of phytotoxic compounds [58]. The morphological adaptations of plants under over-irrigation were described as the formation of aerenchyma tissues in the root cortex with increased root diameters (e.g., potatoes: Solanum tuberosum), the development of adventitious roots near the soil surface (e.g., tomatoes: Lycopersicon esculentum or new Solanum lycopersicum) and a reduction in root diameter (e.g., beet: Beta vulgaris; [58]). Morphological signs of waterlogging stress, such as reduced root growth, were not observed in M. spicata cultivated in the raft components with the highest water volume nor in plants grown in grow pipes. Compared to plants cultivated in the ebb-and-flood components, the root lengths in raft and grow pipes were even 4-fold greater. Oxygen deficiency, as an indicator for waterlogging stress, was not evident as the content of dissolved $\mathrm{O}_{2}$ was sufficient with $8.1 \pm 0.5 \mathrm{mg} / \mathrm{L}$, as the range of $7.1-8.6 \mathrm{mg} / \mathrm{L}$ was reported to be optimal for the production of peppermint (Mentha $\times$ piperita, [59]). However, the slightly lower oxygen content in the gravel substrate components $(7.6 \pm 0.5 \mathrm{mg} / \mathrm{L})$ might have slightly affected root growth in spearmint.

The root lengths in raft and grow pipe components were unusually high and negatively affected the $S: R$ ratio (raft $S: R=1.1 \pm 0.8$; grow pipes $S: R=1.2 \pm 0.4$ ). Herbaceous plants were generally described with an S:R ratio of 2.3 [60], which would correspond to a root length of $29.9 \mathrm{~cm}$ in grow pipe spearmint plants, 1.9 -fold lower (or $49.7 \%$ lower) than the root length observed. M. spicata grown in pots under hydroponic greenhouse conditions in the FishGlassHouse (fertilizer solution with EC: $2011.8 \pm 72.4 \mu \mathrm{S} / \mathrm{cm}$ ) showed an S:R ratio of 3.4 (shoot height: $50.0 \mathrm{~cm}$; root length: $14.5 \mathrm{~cm}$; [55]) and 3.7 (shoot height: 48.4 $\mathrm{cm}$; root length: $13.1 \mathrm{~cm}$; [61]), which were even higher due to the reduced length of roots. Other species of mint, peppermint (Mentha x piperita) and Japanese mint (Mentha arvensis), 
showed S:R ratios of $3.1 \pm 0.23$ (pot culture, 4 months grow; [62]) and approximately 6.5 (deep water culture: DWC, calculated by dry weight, 60 DAT; [63]). In our study, M. spicata in the gravel media substrate components achieved an S:R ratio of $2.1 \pm 0.5$ (Table 2) which was more comparable to reported shoot-and-root ratios. M. spicata grown in the ebb-and-flood gravel media components had a greater growth performance when only the length ratios of the shoots and roots are considered. This is an indication of a poorly balanced nutrient availability in the raft and grow pipe components, which resulted in excessive root elongation, e.g., indicated by the absence of phosphorus in soil [64]. In raft components, the nutrient stratification seemed to have been vertically distributed (due to the low nutrient load in aquaponics compared to hydroponic conditions) with the highest water volume used [65] similar to the deep flow technique (DFT), more than $5 \mathrm{~cm}$ to $1 \mathrm{~m}$ deep [66,67], whereas in the grow pipe components, nutrients were horizontally ejected and clogging occurred [16]. In both components, nutrient availability for short young roots was suboptimal, so that root elongation to the best possible nutrient density took place. In contrast, in the ebb-and-flood gravel components, the nutrients were supplied to each vertical root position by the periodic flooding of the channel and root elongation did not occur. However, it must be considered that in the gravel substrate components, two plants died directly at the inlet positions (Figures 2 and 3), probably due to insufficient nutrient supply. Thus, ebb-and-flood gravel substrate components showed better morphological parameters of $M$. spicata. However, the management effort was substantially higher (e.g., rinsing and moving of gravel; [68]) and spearmint developed significantly lower numbers of leaves, which is economically more important than root lengths. The raft components presumably promoted an adverse stratification of nutrients; therefore, the height of the channels could be reduced in order to decrease the water volume. The grow pipe components drained the nutrients due by the small pipe diameter; hence, the pipe dimensions should be increased, e.g., by converging the dimensions (length, width, volume) of the raft and grow pipe components (reducing volume of raft channels $\downarrow$; increasing diameter of grow tubes $\uparrow$ ), as described for a hydroponic deep flow technique (DFT) with a depth of 5-15 cm [69].

Root growth of M. spicata at specific positions inside the three components was not significantly different due to the high variations in growth, except at Position 7 with the lowest root development in gravel spearmint roots (Figure 3). The growth evolution from the inlet (Position 1) to the outlet (Position 7) showed a sigmoid mint root growth performance in all components, indicating different and non-optimized culture conditions. Spearmint grown in raft components had the smallest variations in root fresh weight with the highest coefficient of determination $\left(R^{2}=0.82\right)$, followed by gravel plants $\left(R^{2}=0.35\right)$ and plants cultured in grow pipes $\left(R^{2}=0.21\right)$. In general, root growth in each component was not uniform and should be optimized (see above). Future studies should evaluate the optimal dimensions of raft and grow pipe components in the aquaponic production of $M$. spicata under co-production of $C$. gariepinus.

\subsubsection{Leaf Development}

The leaf number of $M$. spicata was highest in plants cultured in grow pipes $(770.0 \pm$ 224.4) and was not significantly different than spearmint grown in raft components (610.5 \pm 371.5 ), whereas leaf numbers of raft plants were not significantly different to gravel media substrate plants $(499.8 \pm 228.4$; grow pipes $>$ gravel; raft $=$ grow $\mathrm{pipes} / \mathrm{raft}=$ gravel; Table 2). In general, leaf numbers were high and showed a high degree of variability and plants grew strongly in width. Comparable leaf numbers of $M$. spicata were reported in hydroponic pot cultures with $528.61 \pm 112.46$ leaves [61] and $508.8 \pm 96.6$ leaves [55] on ebb-end-flood tables in the FishGlassHouse with a water depth of $4 \mathrm{~cm}$ and a comparable culture duration. However, M. spicata can reach a higher number of leaves, from 700-1500, which was reported in spearmint cultured in a sterile hydroponic system and approximately 300 leaves from mint, grown in a hydroponic liquid solution in vitro [70], which shows that other factors such as fungi and/or bacteria might be involved in the growth and 
leaf development. In contrast, $M$. spicata, cultivated in DFT hydroponics fertilized by an artificial nutrient solution, showed a substantially lower number of $117.0 \pm 14.72$ leaves [52]. A comparable leaf number of $621.63 \pm 7.34$ was reported under aquaponic conditions with the production of Nile tilapia (O. niloticus), which is similar to spearmint cultivated in the raft and grow pipe components [47], suggesting unknown biological factors in the aquaponics solution that are able to increase the leaf number in spearmint.

$M$. spicata leaf relative chlorophyl content (SPAD) was not significantly different between plants of the different components (Table 2 ) and had a calculated mean value of $29.8 \pm 1.4 \%(n=3)$. Comparable SPAD values were reported in M. spicata grown in rooftop gardens and cultivated in different pot substrates with $27.7 \%$ (coir 80\%, perlite 20\%), $31.2 \%$ (coir $50 \%$, perlite $50 \%$ ) and $32.6 \%$ (coir $20 \%$, perlite $80 \%$; [71]). Substantially higher SPAD values of $46.4 \%$ [61] and 53.8\% [55] were found in pots under hydroponic conditions in the FishGlassHouse. However, conductivity was 35\% higher $(2011.8 \mu \mathrm{S} / \mathrm{cm})$ and leaf chlorophyll level was increased by the use of commercial fertilizer. From Japanese mint $(M$. arvensis), a SPAD value of approximately $42 \%$ was observed in old leaves cultivated under hydroponic conditions with an electrical conductivity of $1900-2000 \mathrm{mS} / \mathrm{cm}, 31.4-34.8 \%$ higher than measured in the sump in the present study. Thus, SPAD values from M. spicata grown in aquaponics are scarce. However, spearmint irrigated with unfertilized process water of intensive $C$. gariepinus production showed higher SPAD values between $40.7 \%$ [61] and $43.4 \%$ [55], with differences of $26.8 \%$ and $31.3 \%$, higher than the mean SPAD level of M. spicata cultivated in the three components. It can be concluded that the nutrient composition of the aquaculture effluents from the intensive African catfish production was not optimal in the present study due to the reduced chlorophyll content of spearmint leaves. Still, the plants of the raft and grow pipe components showed a comparable and higher number of leaves to what has been described in earlier studies, and these components can be recommended for spearmint production. It would be advantageous to obtain high quality plants by: (A) increasing the nutrient content of the aquaculture effluent water by slightly elevating the stocking density of fish (probably by approximately $10 \%$ ); and (B) concentrating the aquaponic nutrient solution through artificial evaporation of the water content in the hydroponic recirculating system. Regarding the influence of nitrogen on plant growth, a linear relationship was found between: (i) SPAD, (ii) chlorophyll, (iii) nitrogen content of plant leaves, and (iv) fertilizer nitrogen amount and was described as a method for $\mathrm{N}$ assessment, e.g., for tomatoes (Solanum lycopersicum; [72]) and wheat (Triticum aestivum variety Sonalika; [73]). Thus, for the aquaponic production of M. spicata, the nutrient levels of the process water could be enhanced in order to achieve a higher relative chlorophyll content.

\section{Conclusions}

Spearmint (M. spicata) cultivated in gravel, raft and grow pipes showed a good growth performance with the irrigation of aquaculture effluent water from intensive African catfish (C. gariepinus) production under decoupled aquaponics. The highest mean biomass yield was found in the raft components (1275.6 $\pm 33.4 \mathrm{~g})$, followed by grow pipes $(1042.0 \pm 35.8$ g) and ebb-and-flood gravel media substrate $(686.3 \pm 98.2 \mathrm{~g})$. Plant heights above ground were not different between the components. However, root lengths and root fresh weights were two-fold and four-fold higher in the raft and grow pipe components (raft = grow pipes > gravel) as an indication of suboptimal culture conditions in the gravel component.

The leaf number was significantly highest in the grow pipe components (770.0 \pm 224.4$)$, compared to the gravel media substrate channels $(499.8 \pm 228.4)$ and the leaf number of M. spicata cultivated in the raft components $(610.5 \pm 371.5)$ was not different to the other components (grow pipes $>$ gravel; raft $=$ grow pipes $/ \mathrm{raft}=$ gravel). The quality of spearmint leaves was moderate due to the reduced relative chlorophyll content (SPAD) and could be optimised by increasing the nutrients associated with an increase in the number of fish or through the condensation of process water nutrients by evaporation. 
In summary, the gravel substrate components cannot be recommended for the cultivation of spearmint due to reduced growth performance and increased maintenance effort (washing, moving). The cultivation of M. spicata in raft and grow pipe components is optimal due to the increased development of leaves. However, technical modifications can be recommended for future studies, increasing the pipe diameter for grow pipes and reducing the channel height for raft components. If the sigmoidal effects of root growth in the grow pipe components can be reduced, this hydroponic subsystem is very well suited also for e.g., vertical industrial constructions with multiple pipe installations. Vertically, over 400 plants can be grown in one frame on $\approx 20 \mathrm{~m}^{2}$ of space which is equivalent to about 2000 spearmint on $100 \mathrm{~m}^{2}$ and $\approx 2580 €$ outcome at $1.29 €$ per plant on the market; this is equivalent to $18,060 €$ within 50 days of cultivation at seven harvests per annum which is $84 \%$ higher compared to the gravel and raft components ( $2844 €$ ) and $79 \%$ higher to grow pipes $(3793 €)$. In contrast, the raft system required a higher volume of water and can be used for hobby production or in regions with a better water supply. Both components belong to soilless plant cultivation ("aquaponics s.s.") and might also be used in aquaponics gardening (s.l.; after Palm et al., 2018 [1]), potentially increasing leaf growth in order to produce spearmint essential oils or fresh plants for local markets.

Author Contributions: All authors contributed to several aspects of the study, specifically: conceptualization, U.K., S.A. and H.W.P.; methodology, J.Z.; software, U.K.; validation, U.K., S.A. and H.W.P.; formal analysis, U.K., S.A. and H.W.P.; investigation, U.K.; resources, U.K.; data curation, J.Z., U.K., S.A. and H.W.P.; writing—original draft preparation, U.K., S.A. and H.W.P.; writing—review and editing, U.K., S.A. and H.W.P.; visualization, U.K.; supervision, U.K., H.W.P. and S.A.; project administration, H.W.P. and U.K.; funding acquisition, H.W.P. and U.K. All authors have read and agreed to the published version of the manuscript.

Funding: We thank the Ministry of Agriculture, Environment and Consumer Protection of MecklenburgWestern Pomerania (Germany), the European Union and EIP-AGRI operational groups for supporting research in aquaponics fish and plant production ('Aquaponik in MV', BNRZD: 13903000 0103; WM-EIP-0007-15). This project was funded through the pilot project "FishGlassHouse: Innovationsinitiative zur ressourceneffizienten Nahrungsmittelproduktion in MV" (European Fisheries Fund-EFF, grant number: VI-560/730-32616-2013/025). We acknowledge financial support from the Deutsche Forschungsgemeinschaft and Universität Rostock within the funding programme Open Access Publishing.

Institutional Review Board Statement: Not applicable.

Informed Consent Statement: Not applicable.

Data Availability Statement: Not applicable.

Conflicts of Interest: The authors declare no conflict of interest.

\section{References}

1. Palm, H.W.; Knaus, U.; Appelbaum, S.; Goddek, S.; Strauch, S.M.; Vermeulen, T.; Jijakli, M.H.; Kotzen, B. Towards commercial aquaponics: A review of systems, designs, scales and nomenclature. Aquac. Int. 2018, 26, 813-842. [CrossRef]

2. Thorarinsdottir, R.; Kledal, P.R.; Skar, S.L.G.; Sustaeta, F.; Ragnarsdottir, K.V.; Mankasingh, U.; Pantanella, E.; van de Ven, R.; Shultz, R.C. Aquaponics Guidelines. 2015; 64p. Available online: https:/ / skemman.is/handle/1946/23343?locale=en (accessed on 12 November 2021).

3. Maucieri, C.; Nicoletto, C.; Junge, R.; Schmautz, Z.; Sambo, P.; Borin, M. Hydroponic systems and water management in aquaponics: A review. Ital. J. Agron. 2018, 11. [CrossRef]

4. Kloas, W.; Groß, R.; Baganz, D.; Graupner, J.; Monsees, H.; Schmidt, U.; Staaks, G.; Suhl, J.; Tschirner, M.; Wittstock, B.; et al. A new concept for aquaponic systems to improve sustainability, increase productivity, and reduce environmental impacts. Aquac. Environ. Interact. 2015, 7, 179-192. [CrossRef]

5. Castillo-Castellanos, D.; Zavala-Leal, I.; Ruiz-Velazco, J.M.; Radilla-García, A.; Nieto-Navarro, J.T.; Romero-Bañuelos, C.A.; González-Hernández, J. Implementation of an experimental nutrient film technique-type aquaponic system. Aquac. Int. 2016, 24, 637-646. [CrossRef]

6. Knaus, U.; Pribbernow, M.; Xu, L.; Appelbaum, S.; Palm, H.W. Basil (Ocimum basilicum) Cultivation in Decoupled Aquaponics with Three Hydro-Components (Grow Pipes, Raft, Gravel) and African Catfish (Clarias gariepinus) Production in Northern Germany. Sustainability 2020, 12, 8745. [CrossRef] 
7. Pasch, J.; Ratajczak, B.; Appelbaum, S.; Palm, H.W.; Knaus, U. Growth of Basil (Ocimum basilicum) in DRF, Raft, and Grow Pipes with Effluents of African Catfish (Clarias gariepinus) in Decoupled Aquaponics. AgriEngineering 2021, 3, 92-109. [CrossRef]

8. Pasch, J.; Appelbaum, S.; Palm, H.W.; Knaus, U. Growth of Basil (Ocimum basilicum) in Aeroponics, DRF, and Raft Systems with Effluents of African Catfish (Clarias gariepinus) in Decoupled Aquaponics (s.s.). AgriEngineering 2021, 3, 559-574. [CrossRef]

9. Love, D.C.; Fry, J.P.; Li, X.; Hill, E.S.; Genello, L.; Semmens, K.; Thompson, R.E. Commercial aquaponics production and profitability: Findings from an international survey. Aquaculture 2015, 435, 67-74. [CrossRef]

10. Tridge Overview of Mint Imports to Germany. 2021. Available online: https:/ /www.tridge.com/intelligences/mint/DE (accessed on 16 July 2021).

11. CBI-The European Market Potential for Fresh Herbs. 2021. Available online: https://www.cbi.eu/market-information/freshfruit-vegetables / fresh-herbs/market-potential (accessed on 16 July 2021).

12. Espinosa Moya, E.A.; Angel Sahagún, C.A.; Mendoza Carrillo, J.M.; Albertos Alpuche, P.J.; Álvarez-González, C.A.; MartínezYáñez, R. Herbaceous plants as part of biological filter for aquaponics system. Aquac. Res. 2016, 47, 1716-1726. [CrossRef]

13. Kotzen, B.; Appelbaum, S. An Investigation of Aquaponics Using Brackish Water Resources in the Negev Desert. J. Appl. Aquac. 2010, 22, 297-320. [CrossRef]

14. Knaus, U.; Wenzel, L.; Appelbaum, S.; Palm, H.W. Aquaponics (s.l.) Production of Spearmint (Mentha spicata) with African Catfish (Clarias gariepinus) in Northern Germany. Sustainability 2020, 12, 8717. [CrossRef]

15. Shete, A.; Verma, A.; Chadha, N.K.; Prakash, C.; Chandrakant, M.; Nuwansi, K.K.T. Evaluation of different hydroponic media for mint (Mentha arvensis) with common carp (Cyprinus carpio) juveniles in an aquaponic system. Aquac. Int. 2017, 25, 1291-1301. [CrossRef]

16. Somerville, C.; Cohen, M.; Pantanella, E.; Stankus, A.; Lovatelli, A. Small-Scale Aquaponic Food Production. Integrated Fish and Plant Farming; FAO Fisheries and Aquaculture Technical Paper No. 589; FAO: Rome, Italy, 2014; p. 262.

17. Brämick, U. Jahresbericht zur Deutschen Binnenfischerei 2009. Available online: https://www.bmel-statistik.de/ernaehrungfischerei/fischerei/aquakultur/ (accessed on 16 July 2021). (In German).

18. Brämick, U. Jahresbericht zur Deutschen Binnenfischerei und Binnenaquakultur 2019. Available online: https://www.bmelstatistik.de/ernaehrung-fischerei/fischerei/aquakultur/ (accessed on 16 July 2021). (In German).

19. Pantanella, E. Aquaponics and Sustainability: Production, Quality and Nutrient Efficiency in Sweet Basil and African Catfish. Ph.D. Thesis, Università degli Studi della Tuscia, Viterbo, Italy, 2012; pp. 55-77.

20. Palm, H.W.; Bissa, K.; Knaus, U. Significant factors affecting the economic sustainability of closed aquaponic systems, Part II: Fish and plant growth. AACL Bioflux 2014, 7, 162-175.

21. Dudley, D.H. Aquaponic Design Plans and Everything You Need to Know, 2nd ed.; Howard Publishing: Brentwood, TN, USA, 2018; 630p.

22. Ahmad-Qasem, M.H.; Cánovas, J.; Barrajón-Catalán, E.; Micol, V.; Carcel, J.A.; Garcia-Perez, J.V. Kinetic and compositional study of phenolic extraction from olive leaves (var. Serrana) by using power ultrasound. Innov. Food Sci. Emerg. Technol. 2013, 17, 120-129. [CrossRef]

23. IBM Deutschland GmbH. IBM SPSS Statistics for Windows; Version 27; IBM Deutschland GmbH: Ehningen, Germany, 2011.

24. Microsoft ${ }^{\circledR}$ Corporation. Microsoft Excel@; Microsoft ${ }^{\circledR}$ Corporation: Redmond, WA, USA, 2010.

25. Huisman, E.; Richter, C. Reproduction, growth, health control and aquacultural potential of the African catfish, Clarias gariepinus (Burchell 1822). Aquaculture 1987, 63, 1-14. [CrossRef]

26. Palm, H.W.; Knaus, U.; Wasenitz, B.; Bischoff, A.; Strauch, S. Proportional up scaling of African catfish (Clarias gariepinus Burchell, 1822) commercial recirculating aquaculture systems disproportionally affects nutrient dynamics. Aquaculture 2018, 491, 155-168. [CrossRef]

27. Akinwole, A.; Faturoti, E. Biological performance of African Catfish (Clarias gariepinus) cultured in recirculating system in Ibadan. Aquac. Eng. 2007, 36, 18-23. [CrossRef]

28. Hogendoorn, H.; Jansen, J.; Koops, W.; Machiels, M.; Van Ewijk, P.; Van Hees, J. Growth and production of the African catfish, Clarias lazera (C. \& V.): II. Effects of body weight, temperature and feeding level in intensive tank culture. Aquaculture 1983, 34, 265-285. [CrossRef]

29. Henken, A.; Boon, J.; Cattel, B.; Lobée, H. Differences in growth rate and feed utilization between male and female African catfish, Clarias gariepinus (Burchell 1822). Aquaculture 1987, 63, 221-232. [CrossRef]

30. Van de Nieuwegiessen, P.G.; Olwo, J.; Khong, S.; Verreth, J.; Schrama, J. Effects of age and stocking density on the welfare of African catfish, Clarias gariepinus Burchell. Aquaculture 2009, 288, 69-75. [CrossRef]

31. Taneja, S.; Chandra, S. Mint. In Handbook of Herbs and Spices; Woodhead Publishing Ltd.: Cambridge, UK, 2012; pp. 366-387. [CrossRef]

32. Government of Ontario-Mint. 2021. Available online: http://www.omafra.gov.on.ca/CropOp/en/herbs/culinary/mint.html\# (accessed on 4 August 2021).

33. Vimolmangkang, S.; Sitthithaworn, W.; Vannavanich, D.; Keattikunpairoj, S.; Chittasupho, C. Productivity and quality of volatile oil extracted from Mentha spicata and M. arvensis var. piperascens grown by a hydroponic system using the deep flow technique. $J$. Nat. Med. 2010, 64, 31-35. [CrossRef] 
34. Sabzalian, M.R.; Heydarizadeh, P.; Zahedi, M.; Boroomand, A.; Agharokh, M.; Sahba, M.R.; Schoefs, B. High performance of vegetables, flowers, and medicinal plants in a red-blue LED incubator for indoor plant production. Agron. Sustain. Dev. 2014, 34, 879-886. [CrossRef]

35. Delfine, S.; Loreto, F.; Pinelli, P.; Tognetti, R.; Alvino, A. Isoprenoids content and photosynthetic limitations in rosemary and spearmint plants under water stress. Agric. Ecosyst. Environ. 2005, 106, 243-252. [CrossRef]

36. Lawrence, B.M. Mint: The Genus Mentha. Medicinal and Aromatic Plants_Industrial Profiles; CRC Press/Taylor \& Francis Group: Boca Raton, FL, USA, 2007; p. 547.

37. Akoumianaki-Ioannidou, A.; Rasouli, M.; Podaropoulou, L.; Karapanos, I.; Bilalis, D. Effects of Cultivation System and Fertilization on Seedling Production of Ocimum basilicum L. and Mentha spicata L. Not. Bot. Horti Agrobot. Cluj-Napoca 2015, 43, 131-137. [CrossRef]

38. Treadwell, D.; Hochmuth, G.; Hochmuth, R.; Simonne, E.; Sargent, S.; Davis, L.; Laughlin, W.; Berry, A. Organic Fertilization Programs for Greenhouse Fresh-cut Basil and Spearmint in a Soilless Media Trough System. HortTechnology 2011, 21, 162-169. [CrossRef]

39. Hepler, P.K. Calcium: A Central Regulator of Plant Growth and Development. Plant Cell 2005, 17, 2142-2155. [CrossRef] [PubMed]

40. Kirkby, E.A.; Pilbeam, D.J. Calcium as a plant nutrient. Plant Cell Environ. 1984, 7, 397-405. [CrossRef]

41. Junge, R.; Antenen, N.; Villarroel, M.; Griessler Bulc, T.; Ovca, A.; Milliken, S. Aquaponics Textbook for Higher Education. AQU@TEACH, Erasmus+ 2020. Zenodo, 2020; 340p. Available online: https://zenodo.org/record/3948179 (accessed on 12 November 2021). [CrossRef]

42. Bittsanszky, A.; Uzinger, N.; Gyulai, G.; Mathis, A.; Junge, R.; Villarroel, M.; Kotzen, B.; Komives, T. Nutrient supply of plants in aquaponic systems. Ecocycles 2016, 2, 17-20. [CrossRef]

43. Choudhury, R.P.; Kumar, A.; Garg, A. Analysis of Indian mint (Mentha spicata) for essential, trace and toxic elements and its antioxidant behaviour. J. Pharm. Biomed. Anal. 2006, 41, 825-832. [CrossRef]

44. Kizil, S.; Toncer, O. Influence of different harvest times on the yield and oil composition of spearmint (Mentha spicata L. var. spicata). J. Food Agric. Environ. 2006, 3E4, 135-137. [CrossRef]

45. Zeinali, H.; Arzani, A.; Razmjo, K. Morphological and essential oil content diversity of Iranian mints (Mentha spp.). Iran. J. Sci. Technol. Trans. 2004, 28, 1-9. [CrossRef]

46. Surendran, U.; Chandran, C.; Joseph, E.J. Hydroponic cultivation of Mentha spicata and comparison of biochemical and antioxidant activities with soil-grown plants. Acta Physiol. Plant. 2017, 39, 26. [CrossRef]

47. Espinosa-Moya, A.; Alvarez-Gonzalez, A.; Albertos-Alpuche, P.; Guzman-Mendoza, R.; Martínez-Yáñez, R. Growth and development of herbaceous plants in aquaponic systems. Acta Univ. 2018, 28, 1-8. [CrossRef]

48. Resh, H.M. Hydroponic Food Production: A Definitive Guidebook for the Advanced Home Gardener and the Commercial Hydroponic Grower, 7th ed.; CRC Press, Taylor \& Francis Group: Boca Raton, FL, USA, 2012; 560p, Available online: https:/ /www.taylorfrancis.com/ books/mono/10.1201/b12500/hydroponic-food-production-howard-resh (accessed on 28 November 2021).

49. Pascual, M.P.; Lorenzo, G.A.; Gabriel, A. Vertical Farming Using Hydroponic System: Toward a Sustainable Onion Production in Nueva Ecija, Philippines. Open J. Ecol. 2018, 8, 25-41. [CrossRef]

50. Krishan, K.; Agrawal, E.R.; Tripathi, M.P.; Yadav, U. Fabrication and performance evaluation of a shaped frame hydroponic system for leafy garlic. J. Pharmacogn. Phytochem. 2020, 9, 688-692. [CrossRef]

51. Zade, N.S.E.; Sadeghi, A.; Moradi, P. Streptomyces strains alleviate water stress and increase peppermint (Mentha piperita) yield and essential oils. Plant Soil 2019, 434, 441-452. [CrossRef]

52. Chrysargyris, A.; Nikolaidou, E.; Stamatakis, A.; Tzortzakis, N. Vegetative, physiological, nutritional and antioxidant behavior of spearmint (Mentha spicata L.) in response to different nitrogen supply in hydroponics. J. Appl. Res. Med. Arom. Plants 2017, 6, 52-61. [CrossRef]

53. Khorasaninejad, S.; Mousavi, A.; Soltanloo, H.; Hemmati, K.; Khalighi, A. The effect of salinity stress on growth parameters, essential oil yield and constituent of peppermint (Mentha piperita L.). World Appl. Sci. J. 2010, 11, 1403-1407.

54. Chand, S.; Pandey, A.; Patra, D.D. Influence of nickel and lead applied in combination with vermicompost on growth and accumulation of heavy metals by Mentha arvensis Linn. cv. 'Kosi'. IJNPR 2012, 3, 256-261.

55. Hübner, H.-D.D. Einfluss von Biohumin ${ }^{\circledR}$ auf das Wachstum der Marokkanischen Minze (Mentha spicata L.) und Basilikum (Ocimum basilicum L.) unter extensiver und intensiver aquaponischer Produktion des Afrikanischen Raubwelses Clarias gariepinus (Burchell, 1822). Master's Thesis, University of Rostock, Rostock, Germany, 2018; 106p. (In German).

56. Robinson, D. The responses of plants to non-uniform supplies of nutrients. New Phytol. 1994, 127, 635-674. [CrossRef]

57. Wilson, J.B. A Review of Evidence on the Control of Shoot: Root Ratio, in Relation to Models. Ann. Bot. 1988, 61, 433-449. [CrossRef]

58. Franco, J.A.; Bañón, S.; Vicente, M.J.; Miralles, J.; Martínez-Sánchez, J.J. Review Article:Root development in horticultural plants grown under abiotic stress conditions-A review. J. Hortic. Sci. Biotechnol. 2011, 86, 543-556. [CrossRef]

59. Nozzi, V.; Graber, A.; Schmautz, Z.; Mathis, A.; Junge, R. Nutrient Management in Aquaponics: Comparison of Three Approaches for Cultivating Lettuce, Mint and Mushroom Herb. Agronomy 2018, 8, 27. [CrossRef]

60. Poorter, H.; Nagel, O. The role of biomass allocation in the growth response of plants to different levels of light, $\mathrm{CO}_{2}$, nutrients and water: A quantitative review. Aust. J. Plant Physiol. 2000, 27, 595-607. 
61. Küchenmeister, C. Vergleich von Pflanzenwachstums- und Qualitätsparametern bei Marokkanischer Minze (Mentha spicata, L.) und Basilikum (Ocimum basilicum, L.) unter extensiver und intensiver aquaponischer Produktion des Afrikanischen Raubwelses Clarias gariepinus (Burchell, 1822). Master's Thesis, University of Rostock, Rostock, Germany, 2018; 91p. (In German).

62. Khorasaninejad, S.; Mousavi, A.; Soltanloo, H.; Hemmati, K.; Khalighi, A. The effect of drought stress on growth parameters, essential oil yield and constituent of Peppermint (Mentha piperita L.). J. Med. Plants Res. 2011, 5, 5360-5365. [CrossRef]

63. Janpen, C.; Kanthawang, N.; Inkham, C.; Tsan, F.Y.; Sommano, S.R. Physiological responses of hydroponically-grown Japanese mint under nutrient deficiency. PeerJ. 2019, 7, e7751. [CrossRef]

64. Kafkafi, U. Chapter 2: Funtions of the root system. In Soilless Culture: Theory and Practice; Raviv, M., Lieth, J.H., Eds.; Elsevier B.V.: Amsterdam, The Netherlands, 2008; pp. 13-40. Available online: https://www.sciencedirect.com/science/article/pii/B9780444 529756500046 (accessed on 28 November 2021).

65. Yep, B.; Zheng, Y. Aquaponic trends and challenges-A review. J. Clean. Prod. 2019, 228, 1586-1599. [CrossRef]

66. Vermeulen, T.; Kamstra, A. The need for systems design for robust aquaponic systems in the urban environment. Acta Hortic. 2013, 1004, 71-77. [CrossRef]

67. Pattillo, D.A. An Overview of Aquaponic Systems: Hydroponic Components; NCRAC Technical Bulletins; 2017; 19p. Available online: https:/ / lib.dr.iastate.edu/ncrac_techbulletins/19 (accessed on 28 November 2021).

68. Rakocy, J.E.; Masser, M.P.; Losordo, T.M. Recirculating Aquaculture Tank Production Systems: Aquaponics-Integrating Fish and Plant Culture; Southern Regional Aquaculture Center Publ. No. 454; United States Department of Agriculture, Cooperative State Research, Education, and Extension Service: Stoneville, MS, USA, 2006; 16p, Available online: https://srac.tamu.edu/categories / view / 24 (accessed on 28 November 2021).

69. Van Os, E.; Gieling, T.H.; Lieth, J.H. Chapter 13: Technical Equipment in Soilless Production Systems. In Soilless Culture: Theory and Practice, 2nd ed.; Raviv, M., Lieth, J.H., Bar-Tal, A., Eds.; Elsevier B.V.: Amsterdam, The Netherlands, 2019 ; pp. 587-635. [CrossRef]

70. Tisserat, B.; Vaughn, S.F. Growth, morphogenesis, and essential oil production in Mentha spicata L. plantlets in vitro. In Vitro Cell. Dev. Biol.-Anim. 2008, 44, 40-50. [CrossRef]

71. Ju, J.-H.; Yoon, Y.-H.; Ju, S.-Y. Influence of Substrates and Hydrogels on Spearmint (Mentha spicata) Growth and Flowering in a Rooftop Garden. HortScience 2021, 56, 629-633. [CrossRef]

72. Jiang, C.; Johkan, M.; Hohjo, M.; Tsukagoshi, S.; Maturo, T. A correlation analysis on chlorophyll content and SPAD value in tomato leaves. Hort. Res. 2017, 71, 37-42. [CrossRef]

73. Islam, M.R.; Haque, K.S.; Akter, N.; Karim, M.A. Leaf chlorophyll dynamics in wheat based on SPAD meter reading and its relationship with grain yield. J. Sci. Agric. 2014, 8, 13-18. [CrossRef] 